\title{
Banking Competition, Housing Prices and
}

\section{Macroeconomic Stability*}

\author{
Javier Andrés ${ }^{\dagger} \quad$ Oscar Arce ${ }^{\ddagger}$
}

February 2009

\begin{abstract}
We develop a dynamic general equilibrium model with an imperfectly competitive bank-loans market and collateral constraints that tie investors' credit capacity to the value of their real estate holdings. Banks set optimal lending rates taking into account the effects of their price policies on their market share and on the volume of funds demanded by each customer. Lending margins have a significant effect on aggregate variables. Over the long run, fostering banking competition increases total consumption and output by triggering a reallocation of available collateral towards investors. However, as regards the short-run dynamics, most macroeconomic variables, including output, credit and housing prices, are more responsive on impact to exogenous shocks in an environment of highly competitive banks. The level of banking competition, through its effects on endogenous lending margins, also affects the degree of persistency of these variables. Specifically, stronger banking competition implies higher (lower) persistency after a monetary (credit-crunch) shock.
\end{abstract}

Keywords: Banking competition, general equilibrium, collateral constraints, housing prices.

JEL numbers: E32, E43, E44, G21.

\footnotetext{
*We are grateful to Larry Christiano, Giancarlo Corsetti, Giovanni Dell'Ariccia, Martin Ellison, Jordi Galí, Matteo Iacoviello, Juan F. Jimeno, David López-Salido, Caterina Mendicino, Gabriel Pérez-Quirós, José-Victor Ríos-Rull, Jesús Saurina, Carlos Thomas, Garry Young and seminar participants at the 2nd International Conference on Macroeconomics at Fundación Rafael del Pino (Madrid), Bank of Spain, CCBS/WGEM Workshop at Bank of England, Sveriges Riksbank workshop on "Household Indebtness, House Prices and the Economy" and EACBN/CREI conference on "Business Cycle Developments, Financial Fragility, Housing and Commodity Prices". The opinions expressed here are solely those of the authors and do not necessarily reflect the views of the Bank of Spain or the Eurosystem.

†Universidad de Valencia and Bank of Spain. E-mail: Javier.Andres@uv.es

${ }^{\ddagger}$ Bank of Spain. Research Department, Alcalá 48, 28014 Madrid. E-mail: o.arce@bde.es
} 


\section{Introduction}

The role of financial intermediaries in the monetary transmission mechanism has been largely neglected in the study of macroeconomic fluctuations. Most dynamic stochastic general equilibrium models (DSGE) that are used to conduct monetary policy analyses incorporate a frictionless financial sector. One key implication of this assumption is that the interest rate set by the central bank coincides with the rate that affects agents' lending and borrowing decisions. However, interest rate spreads are neither zero nor constant in real economies. In fact, differentials between lending and borrowing rates are non-negligible and tend to vary significantly over the cycle, specially at times of financial stress. Furthermore, to the extent that such differentials respond themselves to changes in the monetary policy rate, amplifying or dampening their effects, it becomes clear that a solid framework for monetary policy analysis must consider the optimal pricing rules followed by financial intermediaries.

Bernanke, Gertler and Gilchrist (1999; BGG, henceforth) provide a comprehensive framework that links financial imperfections, interest rate spreads and monetary policy that builds upon the financial accelerator model of Bernanke and Gertler (1989). That theory contends that a positive spread, which they call external finance premium, is a natural outcome in an environment featuring principal-agent conflicts between borrowers and lenders. Such external premium depends inversely on the strength of the borrower's financial position, understood in terms of factors akin to the borrowers capacity to offer collateral (net worth, cash flows,...). BGG show that under reasonable parameterizations of a DSGE model, this financial friction may significantly amplify the effects of real and monetary shocks to the economy.

The framework we develop in this paper shares some features with BGG, chief among them is the role played by the ability of borrowers to supply collateral, yet we start from different grounds. We place imperfect competition among banks in the market for loans 
at the center of the analysis of endogenous interest rate spreads, which we henceforth refer to as lending margins. We think of this departure from the standard Walrasian model of non-intermmediated credit market as a natural route to explore endogenous interest rates spreads. In so doing, we see the mechanism studied here as an alternative to the one emphasized by BGG. Clearly, in reality, both underlying frictions, imperfect competition among banks and asymmetric information and agency costs in lending relationships, are likely to coexist. In short, the central question we pose in this paper is the following: How does the degree of banking competition shapes the response of the economy to different shocks?

To answer the previous question we develop a general equilibrium version of the spatial monopolistic competition model of Salop (1979) in which the borrowers' demand for external funding is modelled explicitly as the outcome of an intertemporal problem of utility maximization. ${ }^{1}$ Overall, the modelling strategy in this paper can be summarized as follows. We pose a banking structure that is compatible with banks charging a positive lending margin and study the determinants of the degree of elasticity of the demand for loans faced by banks and, hence, the behavior of margins. The merit of using a general equilibrium model is that it allows us to pose the reverse question, i.e. how lending margins, in turn, affect aggregate prices and allocations.

As the source of monopolistic power we assume that borrowers suffer a utility cost when traveling to a bank. ${ }^{2}$ Given this cost, borrowers optimally choose period by period their lending bank to maximize the discounted present value of their lifetime utility. Banks set profit-maximizing lending rates taking into account that a higher lending rate

\footnotetext{
${ }^{1}$ The Salop model of monopolistic competition has been extensively used in the literature on banking industrial organization. In this context, this model has been used including, among others, by Chiappori et al. (1995), Freixas and Rochet (1997), Dell'Ariccia (2001) and Repullo (2004).

${ }^{2}$ Of course, this utility cost is a pragmatic modelling device aimed at capturing the sources of monopolistic power by banks over and above those strictly related to literal transportation cost. But even the literal interpretation of geographical distance between lenders and borrowers as an explanatory variable for pricing and availability of credit has received some attention in the empirical literature (see e.g. Petersen and Rajan (2002) and Degryse and Ongena (2005)). Indeed, Petersen and Rajan (1995) use borrower-bank distance as a proxy for monopolistic banking power.
} 
raises unit margins at the cost of reducing the individual demand for funds (intensive margin) and its market share (extensive margin). This modelling choice delivers a good compromise between simplicity and economic content. On one end, the model is sufficiently simple so as to deliver closed-form solutions for the equilibrium lending margins while, on the other, it is rich enough to accommodate a number of complexities that arise from the funding demand side. As regards the latter, we consider an economy with a real estate asset (housing, for short) and endogenous collateral constraints of the kind analyzed by Kiyotaki and Moore (1997) that link the credit capacity of borrowers to the value of their real estate holdings, in the spirit of Iacoviello (2005). Beside collateral constraints, the economy is subject to two standard nominal frictions: nominal (non-indexed) debt and goods-price rigidity. Asset prices (interest rates and the price of housing) are flexible and the total stock of housing is fixed.

In the equilibria we analyze here, (patient) households provide deposits to the banks that use them to make loans to (impatient) entrepreneurs who find it optimal to exhaust their collateral constraints. ${ }^{3}$ Hence, it follows that the demand for funds faced by banks is related not only to the interest rate on loans but also to the expected rate of growth of housing prices and to the tightness of the borrowing constraints, as both affect also the amount of collateral pledged by debtors. Both housing price inflation and maximum leverage ratios are major determinants of the elasticity of the demand for funds at the individual level with respect to the loans interest rate and, thus, of the lending margins. In particular, such elasticity increases whenever housing prices are expected to rise and when borrowing constraints are loose, for in either case a small change in the lending rate triggers a large increase in the amount of collateral pledged by borrowers, thus, raising their demand for funds and inducing lower lending margins. The model also produces a positive relationship between the banks marginal cost, which corresponds to

\footnotetext{
${ }^{3}$ In a previous version (available upon request), we provide an extended model that also includes a group of impatient households that are also financially constrained. The main results presented here are unchanged.
} 
the monetary policy rate, and the lending margin. Thus, the model features a monetary policy accelerator, since a shock to the policy rate translates into a more than proportional change in the lending rate.

As regards the extensive margin, we find that stronger banking competition, say, due to an increase in the number of banks or a fall in transportation costs, goes hand in hand with lower margins. In addition to this intuitive result, we show that the previous determinants of the elasticity of the intensive margin (i.e. housing price inflation, leverage and cost of funds faced by banks) play a similar role with respect to the extensive margin. For instance, when housing price inflation is expected to be high, a marginal increase in the lending rate by a given bank causes a large outflow of borrowers from that bank towards its competitors. Thus, in our model rising housing prices, loose credit limits and low cost of bank liabilities which, arguably are all natural features of housing booms, tend to depress lending margins and to further impulse credit growth.

In order to analyze the macroeconomic effects of imperfect banking competition we first study the steady state properties of the model. The main result here is that stronger competition among banks raises output over the long-run. As banks charge lower margins, the relative user cost of housing for debtors vis-à-vis savers falls, since the user cost is positively related to the lending rate for the former and to the deposits rate to the latter. This, in turn, implies a reallocation of the available stock of housing from savers to debtors who also value houses for their services as collateral. Such reallocation of the pledgeable asset towards debtors rises overall investment, output and consumption. Thus, stronger banking competition "greases the economy's wheels" in the long run.

The effects of banking competition on the economy's short-run dynamics are more complex due to the presence of several competing effects. On the one hand, lower lending margins lead to higher leverage ratios which tend to exacerbate the short-run response of housing prices, consumption and output. On the other hand, low lending margins 
facilitate a faster recovery of the borrowers' net worth and, hence, their borrowing and production capacity in face of an adverse shock. Which of these conflicting forces -shortrun volatility versus persistency- dominates depends crucially on the nature of the shock at place.

For instance, in face of a contractionary monetary shock both housing prices and total output tend to exhibit a larger and more persistent fall as the banking sector becomes more competitive. Following the shock, the subsequent negative debt-deflation and collateral (housing price deflation) effects both get amplified in the presence of strong banking competition and high leverage ratios. On the other hand, as banking competition intensifies, the positive response of lending margins becomes weaker, which tends to mitigate the adverse effects on the previous variables. However, this latter effect is found to be very small in the case of a monetary shock, since positive house price inflation rate after the initial fall in the price level attenuates, to a large extent, the positive effects of higher interest rates on the lending margin. For reasonable parameterizations of the model, the former (negative) net worth effect overcomes the latter (positive) lending margin effect. As regards the magnitude of the overall net effect, we find that the accumulated output loss following an unexpected rise in the policy rate after 40 quarters is around 27 per cent larger in an economy with a fully competitive banking sector than in our benchmark economy with steady state lending margins of 250 basis points per annum. ${ }^{4}$ Hence, in face of monetary shocks, stronger banking competition works as a powerful amplification mechanism of net worth effects.

The previous conclusion, however, does not hold when we study the effects of credit crunch-type shocks that reduce the degree of pledgeability of collateralizable assets. In this case, we show that stricter credit rationing leads banks to pursue aggressive margin

\footnotetext{
${ }^{4} \mathrm{~A}$ similar argument applies with respect to technology shocks, altough the quantitative differences are smaller than in the case of a monetary shock since the prices of maturing debts and housing run in opposite directions, so that the overall effect on the borrowers' net worth is weaker.
} 
increases which, in turn, tend to postpone the economy's recovery for a longer time. Hence, we find that stronger banking competition works to reduce the total output loss over longer horizons by accelerating the recovery. Specifically, we find that the output loss after 40 quarters in the benchmark case is 28 per cent higher than the one that obtain under perfect competition in the loans market.

Our paper is related to several strands of literature on financial frictions and the macroeconomy. Regarding the central hypothesis of imperfect banking competition, the closest models to ours are those by Aliaga-Díaz and Olivero (2006), Mandelman (2006) and Stebunovs (2008). In Aliaga-Díaz and Olivero market power arises from switching costs faced by costumers when trying to move from one bank to another. Mandelman models banking competition as an entry game in which potential competitors face fixed settlement costs and incumbents play strategies aimed at deterring entry. Stebunovs (2008) also provides a model of spatial monopolistic banking competition with endogenous entry of firms, in which new entrants borrow from banks to finance some start-up costs. He finds that stronger monopoly power in the banking industry increases the financial burden faced by borrowers, thus reducing the number of firms in the market and the aggregate level of output. In these circumstances a positive technology shock has a proportionally higher effect on total production than in a perfectly competitive banking environment.

Apart from differences in the strategy followed to model banking competition with respect to the one pursued here, the above papers study non-monetary economies in which banking monopolistic power is the only financial friction. In contrast, key to the arguments developed in the present paper is the idea that investing agents also face borrowing constraints that limit their ability to obtain external finance, linking such constraints to the value of their pledgeable assets. In fact, the relationship between the degree of banking competition and the responsiveness of the main macro aggregates in 
our model hinges crucially on the way in which the two financial frictions -imperfect competition and endogenous borrowing limits- interact with each other. Importantly, the aforementioned models find that weaker banking competition is associated with a larger output response to productivity shocks due to countercyclical lending margins. While our model also features countercyclical lending margins, we emphasize that the main channel through which margins affect our economy is related to the strength of the net worth effects rather than intertemporal substitution effects.

Huelsewig et al. (2006) and Gerali et al. (2008) both feature economies with an imperfectly competitive banking sector, in which banks compete à la Dixit-Stiglitz, and examine the macroeconomic consequences of sluggishness in banks interest rates. Here we are rather interested in exploring the determinants of the elasticity of the demand for funds and, hence, of bank lending margins, and the links between these and some macroeconomic variables. In so doing, we find it natural to assume fully flexible interest rates.

Goodfriend and McCallum (2007), Christiano et al. (2007) and Canzoneri et al. (2008) also provide recent analyses on the role of banks in general equilibrium monetary models although none of them consider imperfect banking competition. Rather, the interest in these papers is to analyze how different banking technologies to produce loans influence the equilibrium determination of interest rates and either amplify or attenuate the effects of macroeconomic shocks. In contrast, we are mainly interested in isolating the macroeconomic effects of imperfect banking competition and, to this aim, we instead consider a very simple technology for loan production.

On the empirical front, Goodhart, Hofmann and Segoviano (2004) using a sample of OECD countries, find that measures aimed at fostering banking competition were associated with an increased sensitivity of bank lending to real estate price movements, thus strengthening the links between bank credit and business cycles. Interestingly, they 
point towards the strengthening of the borrowers' net worth channel following financial liberalization as a prime cause of such increased sensitivity, thus, in line with the results of our model. In a similar vein, Adams and Amel (2005) find that in the U.S. the impact of monetary policy on banks loan originations is weaker in less competitive markets.

The paper is organized as follows. Section 2 introduces the model. Section 3 is devoted to derive the analytical solution of the profit maximization problem solved by the banks. Section 4 contains the analysis of the deterministic steady state of the model. Section 5 discusses fluctuations around the steady-state in response to monetary,technology and financial shocks using a linearized version of the model. Section 6 concludes.

\section{The model}

The economy consists of continuum of households with measure 1, and a continuum of entrepreneurs of mass 1 producing a homogenous consumption good, a continuum of retailers of mass 1 that differentiate the output of the entrepreneurs, a fixed number $n>2$ of banks and a central bank in charge of monetary policy. Households and entrepreneurs obtain utility from consumption of a composite good. Also, the flow of services produced by their housing stocks delivers utility directly to households, while entrepreneurs employ housing services as a production factor. The total housing stock $\bar{H}$, is fixed.

Households and entrepreneurs participate in the credit market either lending or borrowing funds. As in Iacoviello (2005), we assume that the entrepreneurs are less patient so that they discount future utility more heavily than the households. This assumption implies that in the steady state equilibrium households optimally choose to lend while entrepreneurs borrow. Only bank-intermediated credit is available so that the households supply funds (henceforth, deposits) to the banking sector and the latter make loans to the entrepreneurs. We assume that competition in the loans market is imperfect so that 
each bank enjoys some monopolistic power whereas the market for deposits is perfectly competitive. Also, we assume a cash-less economy and abstract from any role of money in the economy beyond that of serving as numeraire.

In order to model imperfect competition in the loans market we use a version of Salop's (1979) circular-city model. Specifically, we assume that entrepreneurs are distributed uniformly on a circumference of unit length. Individual locations vary each period according to an i.i.d. stochastic process. Changing individual locations in that way rules out the possibility that banks learn about lenders position which, in turn, simplifies the analysis by removing dynamic strategic interactions among banks, as those studied by Dell'Ariccia (2001). Banks are located symmetrically on this circumference. Their position is time-invariant. Whenever an entrepreneur asks for credit he has to travel to a bank incurring a utility cost which is proportional to the distance between his and the bank's location. With this spatial environment in mind we next describe the objectives and constraints faced by each type of agent. ${ }^{5}$

\subsection{Households}

Let $C_{t}, H_{t}$, and $L_{t}$ represent, respectively, consumption, housing services and hours worked for a household who has a subjective discount factor $\beta \in(0,1)$ and seeks to maximize

$$
U_{0}=E_{0} \sum_{t=0}^{\infty}(\beta)^{t}\left(\log C_{t}-L_{t}+\vartheta \log H_{t}\right)
$$

subject to the sequence of budget constraints

$$
C_{t}+I_{t}+\frac{\phi I_{t}^{2}}{2 K_{t-1}}+P_{t}^{h}\left(H_{t}-H_{t-1}\right)+D_{t}=W_{t} L_{t}+Q_{t}^{k} K_{t}+\int_{0}^{1} \Gamma_{j t} d j+\sum_{i=1}^{n} \Omega_{t}^{i}+\frac{R_{t-1}^{d} D_{t-1}}{\pi_{t}},
$$

\footnotetext{
${ }^{5}$ The reasons for choosing Salop's approach to imperfect competition, instead of the more popular Dixit-Stiglitz differentiated product framework, are twofold. First, loans are far more homogenous products than those composing the consumption basket; and second, we are interested on exploring endogenous variations of the elasticity of the demand for loans as well as lending margin fluctuations that are not necessarily associated to sticky rates.
} 
and the capital accumulation equation

$$
K_{t}=I_{t}+(1-\delta) K_{t-1}
$$

At the beginning of period $t$ the household receives labor income $W_{t} L_{t}$, where $W_{t}$ is the real wage, and income from renting his capital holdings, $K_{t}$, to entrepreneurs at a real rental price $Q_{t}^{k}$. $\Gamma_{j t}$ and $\Omega_{t}^{i}$ are dividends from ownership of the $j_{t h}$ retail firm and the $i_{t h}$ bank, respectively. $D_{t-1}$ is the real value of nominally risk-free one-period bank deposits carried over from $t-1$, which pay a nominal gross rate $R_{t-1}^{d}$ at the beginning of $t$, and $\pi_{t}$ is the gross inflation rate. $I_{t}$ represents capital investments and the term $\phi\left(I_{t}^{2} / 2 K_{t-1}\right)$ captures capital adjustment costs with a non-negative constant $\phi . H_{t}$ stands for the stock of houses owned by the household and $P_{t}^{h}$ is the unit housing price in terms of consumption goods. Implicit in the layout of the problem is the assumption that the flow of housing services that produce utility to the home-owner is equal to the housing stock. Houses do not depreciate while capital depreciates at a rate $\delta$.

The first order conditions for consumption (4), labor supply (5), owner-occupied housing demand (6), deposits (7) and capital supply (9) are

$$
\begin{gathered}
\frac{1}{C_{t}}=\lambda_{t}, \\
\lambda_{t} W_{t}=1, \\
\lambda_{t} P_{t}^{h}=\frac{\vartheta}{H_{t}}+\beta E_{t}\left(\lambda_{t+1} P_{t+1}^{h}\right), \\
\lambda_{t}=\beta E_{t}\left(\lambda_{t+1} R_{t}^{d} / \pi_{t+1}\right), \\
P_{t}^{k}=1+\phi I_{t} / K_{t-1} \\
\left(P_{t}^{k}-Q_{t}^{k}\right) \lambda_{t}=\beta E_{t}\left\{\lambda_{t+1}\left[\frac{\phi}{2}\left(\frac{I_{t+1}}{K_{t}}\right)^{2}+(1-\delta) P_{t+1}^{k}\right]\right\},
\end{gathered}
$$


where $\lambda_{t}$ is the Lagrange multiplier on the flow of funds constraint (2). The shadow value of installed capital, $P_{t}^{k}$, is the familiar Tobin's $Q$.

We define the housing user cost for a household, denoted by $\varpi_{t}$, as the marginal rate of substitution between consumption of goods and housing services. Combining (4) and (6), we can express the user cost as,

$$
\varpi_{t} \equiv \frac{\vartheta C_{t}}{H_{t}}=P_{t}^{h}-\beta E_{t}\left(P_{t+1}^{h} \frac{C_{t}}{C_{t+1}}\right)
$$

Thus, the user cost for a household is positively related to the current housing price $P_{t}^{h}$ and negatively related to the expected resale price $P_{t+1}^{h}$. It is also positively related to expected consumption growth, as this term captures the utility cost of an extra housing unit due to deferred consumption.

\subsection{Production}

\subsubsection{Entrepreneurs}

The representative entrepreneur produces an intermediate good in an amount $Y_{t}$ using the following constant returns-to-scale technology,

$$
Y_{t}=A_{t}\left(K_{t}^{e}\right)^{\mu}\left(L_{t}^{e}\right)^{(1-\mu-\nu)}\left(H_{t-1}^{e}\right)^{\nu}
$$

where $A_{t}$ is an exogenous productivity index, $K_{t}^{e}$ is capital, $L_{t}^{e}$ is labor and $H_{t}^{e}$ is real estate. Entrepreneurs are assumed to be more impatient than savers, so that their subjective discount factor $\beta^{e}$ satisfies $\beta^{e}<\beta$.

As for the objective function, we assume that an entrepreneur located at point $k \in$ 
$(0,1]$ seeks to maximize the following utility function,

$$
U_{0}^{e}=E_{0} \sum_{t=0}^{\infty}\left(\beta^{e}\right)^{t}\left[\log C_{t}^{e}-\alpha d_{t}^{k, i}\right]
$$

where $C_{t}^{e}, d_{t}^{k, i}$ and $\alpha$ denote consumption, the distance between entrepreneur $k$ and bank $i$, and the utility loss per distance unit, respectively. The entrepreneur faces the following flow of funds constraint

$$
C_{t}^{e}+P_{t}^{h}\left(H_{t}^{e}-H_{t-1}^{e}\right)+R_{t-1}^{e} B_{t-1}^{e} / \pi_{t}=B_{t}^{e}+Y_{t} / X_{t}-W_{t} L_{t}^{e}-Q_{t}^{k} K_{t}^{e}
$$

where $X_{t}$ denotes the markup of final over intermediate goods charged by retailers. Entrepeneurs also face the following borrowing constraint,

$$
B_{t}^{e} \leq m_{t} E_{t} P_{t+1}^{h} \frac{\pi_{t+1}}{R_{t}^{e}} H_{t}^{e}
$$

where $m_{t}<1$. $B_{t}^{e}$ is the real value of a nominal one-period bank loan taken at $t$, and $R_{t}^{e}$ is the gross nominal interest rate on such loan, payable at the beginning of $t+1$. In words, at time $t$ entrepeneurs can only borrow up to a fraction $m_{t}$ of the discounted next-period resale value of their time $t$ stock of real estate.

The first order conditions of the representative entrepreneur for consumption (15), capital demand (16), labor demand (17), debt (18), and housing demand (19) are,

$$
\begin{gathered}
\frac{1}{C_{t}^{e}}=\lambda_{t}^{e}, \\
Q_{t}^{k}=\frac{\mu Y_{t} / X_{t}}{K_{t}^{e}}, \\
W_{t}=\frac{(1-\mu-\nu) Y_{t} / X_{t}}{L_{t}^{e}},
\end{gathered}
$$




$$
\begin{gathered}
\lambda_{t}^{e}=\beta^{e} E_{t}\left(\lambda_{t+1}^{e} \frac{R_{t}^{e}}{\pi_{t+1}}\right)+\xi_{t}^{e} \\
\lambda_{t}^{e} P_{t}^{h}=\beta^{e} E_{t}\left\{\lambda_{t+1}^{e}\left(P_{t+1}^{h}+\frac{\nu Y_{t+1} / X_{t+1}}{H_{t}^{e}}\right)\right\}+\xi_{t}^{e} m_{t} E_{t} P_{t+1}^{h} \frac{\pi_{t+1}}{R_{t}^{e}}
\end{gathered}
$$

We will look at equilibria in which $R_{t}^{e}$ is low enough so that (14) binds and its corresponding multiplier $\xi_{t}^{e}$, is positive. Now, the user cost for an entrepreneur, $\varpi_{t}^{e}$, is given by the ratio of marginal utility of consumption to the expected marginal product of housing properly discounted, i.e.

$$
\varpi_{t}^{e}=E_{t}\left(\frac{\beta^{e} \lambda_{t+1}^{e}}{\lambda_{t}^{e}}\right) \frac{\nu Y_{t+1}}{X_{t+1} H_{t}^{e}}
$$

which using (15) and (19) can be written as

$$
\varpi_{t}^{e}=P_{t}^{h}-E_{t}\left(\beta^{e}\left(\frac{C_{t}^{e}}{C_{t+1}^{e}}\right)+\xi_{t}^{e} m_{t} C_{t}^{e} \frac{\pi_{t+1}}{R_{t}^{e}}\right) P_{t+1}^{h},
$$

which has a similar interpretation as the households user cost except for the fact that $\varpi_{t}^{e}$ features an additional term that captures the value of an additional unit of housing as collateral. This last term is $\xi_{t}^{e} m_{t} C_{t}^{e} E_{t}\left(\pi_{t+1} P_{t+1}^{h}\right) / R_{t}^{e}$.

\subsubsection{Final goods producers}

Aggregate final output $Y_{t}^{f}$ is a composite of different varieties produced by monopolistically competitive retail firms with elasticity of substitution in the consumers preferences $\varepsilon$. A retail firm producing variety $j$ buys the output of competitive wholesale firms and converts it into a variety $Y_{j t}$ that is sold in the market at a price $P_{j t}$. The demand for variety $j$ is given by $Y_{j t}=\left(P_{j t} / P_{t}\right)^{-\varepsilon} Y_{t}^{f}$, where the aggregate price is defined by $P_{t}=\left[\int_{0}^{1}\left(P_{j t}\right)^{1-\varepsilon} d j\right]^{\frac{1}{1-\varepsilon}}$.

Prices are sticky in the retail sector. Following Calvo (1983), each period a random fraction of firms adjust prices. Let $\widetilde{P}_{j, t}$ be the optimal price of the representative firm changing prices at $t$ and $1-\theta$ the probability that a firm adjusts prices. Also we assume 
that those firms that do not set their prices optimally at $t$ follow a simple indexation rule to steady-state inflation of the form $P_{j, t}=\pi P_{j, t-1}$. The optimal price maximizes the expected present discounted value of future dividends subject to the demand function

$$
\widetilde{p}_{j t}=\left(\frac{\varepsilon}{\varepsilon-1}\right) \frac{E_{t} \sum_{\widetilde{k}=0}^{\infty}(\beta \theta)^{\widetilde{k}} \zeta_{j, t, t+\widetilde{k}} m c_{j, t, t+\widetilde{k}} Y_{j, t+\widetilde{k}} \prod_{i=1}^{\widetilde{k}} \pi_{t+i}}{E_{t} \sum_{\widetilde{k}=0}^{\infty}(\beta \theta)^{\widetilde{k}} \zeta_{j, t, t+\widetilde{k}} Y_{j, t+\widetilde{k}} \prod_{i=1}^{\widetilde{k}}(\pi)^{\widetilde{k}-1}},
$$

where $\zeta_{j, t, t+\widetilde{k}}, m c_{j, t, t+\widetilde{k}}$, and $P_{j, t+\widetilde{k}}$ are the firm's discount factor, the marginal cost and the aggregate price, respectively and $\widetilde{p}_{j t}=\frac{\widetilde{P}_{j t}}{P_{t}}$. The aggregate price level satisfies,

$$
1=\left[\theta\left(\frac{\pi}{\pi_{t}}\right)^{1-\varepsilon}+(1-\theta) \widetilde{p}_{t}^{(1-\varepsilon)}\right]^{\frac{1}{1-\varepsilon}}
$$

We assume that retail firms are owned by savers. Then, the relevant discount rate in pricing $\zeta_{j, t, t+\widetilde{k}}$ can be expressed as $E_{t} \zeta_{j, t, t+1}=\beta^{s} E_{t} \lambda_{t+1}^{s} / \lambda_{t}^{s}$. Finally, since retailers do not use other inputs in production, the expected marginal cost of the optimizing firm at $t+\widetilde{k}$ equals the inverse of the markup, $X_{t}$, i.e. $m c_{j, t, t+\widetilde{k}}=m c_{t+\widetilde{k}}=1 / X_{t+\widetilde{k}}$. Thus, the profits of the firms in this sector are $\Gamma_{j t}=\frac{X_{j t}-1}{X_{j t}} Y_{j t}$. Finally note that aggregate output can be expressed either as the CES aggregator over $Y_{j t}(\forall j)$ or as the sum of total production by competitive intermediate firms. Thus in aggregate we write $Y_{t}^{f}=Y_{t}$.

\section{$2.3 \quad$ Banks}

Bank $i$ chooses the interest rate on loans to entrepreneurs $R_{t}^{i, e}$, and the volume of deposits $D_{t}^{i}$, in order to maximize

$$
E_{0} \sum_{t=0}^{\infty} \prod_{s=0}^{t}\left(\beta \frac{C_{s-1}}{C_{s}}\right) \Omega_{t}^{i}
$$

where $\Omega_{t}^{i}$ stands for the bank's dividends, subject to the set of flow of funds constraints

$$
\Omega_{t}^{i}+B_{t}^{i}+R_{t-1}^{d} D_{t-1}^{i} / \pi_{t}=R_{t-1}^{i, e} B_{t-1}^{i} / \pi_{t}+D_{t}^{i}
$$


and the balance-sheet identity, $D_{t}^{i}=B_{t}^{i}{ }^{6}$ Each bank takes all prices, the interest rate $R_{t}^{d}$ (which is set by the central bank), the interest charged on loans made by its competitors, and the entrepreneurs demand for funds functions as given. In order to solve for the optimal loan interest rate rule followed by bank $i$, it is convenient to express its total demand for loans in terms of an intensive and an extensive margin as follows,

$$
B_{t}^{i} \equiv b_{t}^{i} \widetilde{b}_{t}^{i}
$$

where, $b_{t}^{i}$ represents the individual demand for funds by the representative entrepreneur faced by bank $i$ at time $t$ (i.e. the intensive margin), and $\widetilde{b}_{t}^{i}$ denotes the measure of entrepreneurs that borrow from that bank (i.e. the extensive margin).

The first order conditions of this profit maximization problem can then be written in compact form as,

$$
R_{t}^{i, e}=R_{t}^{d}+\frac{1}{\Lambda_{t}^{i}+\widetilde{\Lambda}_{t}^{i}}
$$

where, $\Lambda_{t}^{i} \equiv-\frac{\partial b_{t}^{i}}{\partial R_{t}^{i, e}} \frac{1}{b_{t}^{i}}$ represents the semi-elasticity of the entrepreneurial debt intensive margin, respectively, while $\widetilde{\Lambda}_{t}^{i} \equiv-\frac{\partial \widetilde{b}_{t}^{i}}{\partial R_{t}^{i, e}} \frac{1}{\widetilde{b}_{t}^{i}}$ denotes the semi-elasticity of the extensive margin. Later in section 3, we derive the exact expression for $\Lambda_{t}^{i}$ and $\widetilde{\Lambda}_{t}^{i}$.

\subsection{Monetary policy}

We assume that the central bank sets the interest rate $R_{t}^{d}$ according to a Taylor rule of the form:

$$
R_{t}^{d}=\rho_{r} R_{t-1}^{d}+\left(1-\rho_{r}\right)\left(\frac{\pi}{\beta^{s}}+\rho_{\pi}\left(\pi_{t}-\pi\right)\right)+\epsilon_{t}^{R},
$$

\footnotetext{
${ }^{6}$ This is a very stylized representation of a banks balance-sheets along which we are abstracting, among other things, from reserve requirements.
} 
that represents a smoothed response of the interest rate to deviations of current inflation from its steady-state target, $\pi$. The term $\epsilon_{t}^{R}$ follows an autorregresive process,

$$
\epsilon_{t}^{R}=\varsigma^{R} \epsilon_{t-1}^{R}+u_{t}^{R},
$$

where $u_{t}^{R}$ is a white noise shock process with zero mean and and variance $\sigma_{R}^{2}$.

\subsection{Equilibrium}

Given a sequence of shocks, we define a symmetric equilibrium in which all banks set the same interest rates $\left(R_{t}^{i, e}=R_{t}^{e}\right.$, for all $\left.i=1, \ldots, n\right)$, maintain the same volume of deposits and loans $\left(D_{t}^{i}=D_{t}^{B}, B_{t}^{i}=B_{t}^{B}\right.$, for all $\left.i=1, \ldots, n\right)$ and, hence, dividends $\left(\Omega_{t}^{i}=\Omega_{t}\right)$, as an allocation $\left\{C_{t}, C_{t}^{e}, H_{t}, H_{t}^{e}, L_{t}, L_{t}^{e}, K_{t}, K_{t}^{e}, I_{t}, D_{t}, D_{t}^{B}, B_{t}^{e}, B_{t}^{B}, \Omega_{t}, \Gamma_{t}\right\}_{t=0}^{\infty}$ and a vector of prices $\left\{P_{t}, P_{t}^{h}, P_{t}^{k}, \widetilde{P}_{t}, W_{t}, X_{t}, Q_{t}^{k}, R_{t}^{d}, R_{t}^{e}\right\}_{t=0}^{\infty}$, such that the households and the entrepreneurs solve their respective maximization problem and all markets clear: (goods) $Y_{t}=C_{t}+C_{t}^{e}+I_{t}+\frac{\phi\left(I_{t}\right)^{2}}{2 K_{t-1}}$, (housing) $\bar{H}=H_{t}+H_{t}^{e}$, (capital) $K_{t}=K_{t}^{e}$, (labor) $L_{t}=L_{t}^{e}$, (deposits) $D_{t}=n D_{t}^{B}$, and (loans) $B_{t}^{e}=n B_{t}^{B}$.

\section{Equilibrium lending margins}

In this section we study the determinants of the equilibrium lending margin, $R_{t}^{e}-R_{t}^{d}$. We derive the analytical expressions for the semi-elasticities appearing in the first order condition of the banks' problem, (21). In order to obtain an expression for the lending rate, we first obtain a closed form solution for the individual demand for funds function, $B_{t}^{e}$. In so doing we exploit the familiar result that under logarithmic utility an entrepreneur saves a fraction $\beta^{e}$ of his net worth and consumes the remaining fraction, $1-\beta^{e}$. 
An entrepreneur's net worth can be written as

$$
N W_{t}^{e}=P_{t}^{h} H_{t-1}^{e}+\nu Y_{t} / X_{t}-\frac{R_{t-1}^{e}}{\pi_{t}} B_{t-1}^{e} .
$$

That is, the net worth is composed of the total value of the beginning-of-period real estate holdings, $P_{t}^{h} H_{t-1}^{e}$, plus the output share accruing to the entrepreneur's stock of real estate, $\nu Y_{t} / X_{t}$, net of maturing debts, $R_{t-1}^{e} B_{t-1}^{e} / \pi_{t}$. Now, using the constraint (13), we obtain the following expressions for the entrepreneur's time $t$ total consumption

$$
C_{t}^{e}=\left(1-\beta^{e}\right) N W_{t}^{e},
$$

and,

$$
P_{t}^{h} H_{t}^{e}-B_{t}^{e}=\beta^{e} N W_{t}^{e}
$$

Then, combining (25) with the borrowing constraint (14) holding as an equality, we can write the demand for funds of an entrepreneur who travels to bank $i$ at time $t$ as

$$
B_{t}^{e}=\frac{\beta^{e} N W_{t}^{e}}{P_{t}^{h}\left[m_{t} E_{t}\left(P_{t+1}^{h} \pi_{t+1}\right) / R_{t}^{i, e}\right]^{-1}-1} .
$$

(Note that we are using the superscript $i$ on $R_{t}^{i, e}$ in (26) whereas we write $R_{t-1}^{e}$ in (23). We follow this notational convention to emphasize that the entrepreneur's banking choice at $t-1$ is irrelevant for the current one. Furthermore, $R_{t-1}^{e}$ is taken as an element of a past symmetric equilibrium and, hence, it is common for all banks.)

From (26), we learn that the demand for funds by an entrepreneur borrowing from bank $i$ depends positively on his net worth, $N W_{t}^{e}$, the loan-to-value ratio, $m_{t}$, and the expected housing inflation rate $E_{t} \pi_{t+1}^{h}$, where $\pi_{t+1}^{h} \equiv P_{t+1}^{h} / P_{t}^{h}$, and negatively on the expected real interest rate $E_{t}\left(R_{t}^{i, e} / \pi_{t+1}\right)$.

The previous expression (26) allows us to arrive at the following closed-form solution 
for the semi-elasticity of bank $i$ 's intensive margin,

$$
\Lambda_{t}^{i}=\left\{R_{t}^{i, e}-m_{t} E_{t}\left(\pi_{t+1}^{h} \pi_{t+1}\right)\right\}^{-1} .
$$

From (27) we see that entrepreneurial debt is more sensitive to changes in the nominal lending rate when expected capital gains from housing investments, in nominal terms, $E_{t}\left(\pi_{t+1}^{h} \pi_{t+1}\right)$, are high. This reflects the fact that high expected capital gains tend to amplify the effect of a change in $R_{t}^{i, e}$ on the amount of pledgeable collateral in hands of entrepreneurs, and hence, the response of their demand for funding. Also, higher values of $m_{t}$ tend to raise $\Lambda_{t}^{i}$ when there is expected asset price inflation whereas the opposite effect obtains when $E_{t}\left(\pi_{t+1}^{h} \pi_{t+1}\right)<0$.

We next focus on the extensive margin of the demand for funds faced by bank $i$. We proceed by first identifying the entrepreneur $k$ located between banks $i$ and $i-1$ who is indifferent between the loan rates offered by both banks (henceforth, the "pivotal entrepreneur"). We do this by equalizing the pivotal entrepreneur's total discounted utility values (i.e. the time $t$ version of (12)) that would obtain conditional on borrowing at time $t$ from bank $i$ as opposed to bank $i+1$. To clear the desk, it is helpful to note that current consumption, $C_{t}^{e}$, according to (23) and (24), is independent of the entrepreneur's current banking choice. Also, as each borrower decides optimally his lending bank period by period and without any history-given constraint, we learn that the utility-cost terms $d_{s}^{k, i}$ for $s>t$, are independent of the current banking choice, as well. Hence, the pivotal entrepreneur is implicitly identified through the following equality,

$$
E_{t}\left\{\sum_{s=t+1}^{\infty}\left(\beta^{e}\right)^{s-t} \log C_{s}^{e, i}\right\}-\alpha d_{t}^{k, i}=E_{t}\left\{\sum_{s=t+1}^{\infty}\left(\beta^{e}\right)^{s-t} \log C_{s}^{e, i+1}\right\}-\alpha d_{t}^{k, i+1}
$$

where $C_{s}^{e, i}$ and $C_{s}^{e, i+1}$ are interpreted as the optimal level of consumption conditional on the entrepreneur having obtained a loan at time $t$ from bank $i$ or bank $i+1$, respectively. 
An important feature of this problem is that the current banking choice displays persistent effects on consumption at all future dates. To see this, we combine (23) and (25) with (14) holding as an equality and express entrepreneurial net worth at $t+1$ as a function of its own lagged value,

$$
N W_{t+1}^{e, i}=\beta^{e} \frac{\nu Y_{t+1} /\left(X_{t+1} H_{t}^{e}\right)+P_{t+1}^{h}-m_{t} E_{t}\left(P_{t+1}^{h} \pi_{t+1}\right) / \pi_{t+1}}{P_{t}^{h}-m_{t} E_{t}\left(P_{t+1}^{h} \pi_{t+1}\right) / R_{t}^{i, e}} N W_{t}^{e} .
$$

Importantly, the ratio $Y_{t+1} /\left(X_{t+1} H_{t}^{e}\right)$ is independent of the lending rate, $R_{t}^{i, e}$. This is due to the fact that the markets for capital and labor are both competitive, which together with a Cobb-Douglas technology imply that the optimal output-housing ratio can be expressed as a function of the wage and the rental price of capital. Formally, combining (11), (16) and (17), we learn that,

$$
\frac{Y_{t+1} / X_{t+1}}{H_{t}}=\left\{\frac{A_{t}}{X_{t+1}}\left(\frac{1-\mu-\nu}{W_{t+1}}\right)^{1-\mu-\nu}\left(\frac{\mu}{Q_{t+1}^{k}}\right)^{\mu}\right\}^{1 / \nu}
$$

Hence, the only channel through which $R_{t}^{i, e}$ affects $N W_{t+1}^{e, i}$ is through the direct effect of $R_{t}^{i, e}$ on the (constrained) amount of external funding that the entrepreneur borrows at $t$.

The following expression extends (29) to future dates,

$$
N W_{t+s+1}^{e, i}=\beta^{e} \frac{\nu Y_{t+s+1} /\left(X_{t+s+1} H_{t+s}^{e}\right)+P_{t+s+1}^{h}-m_{t} E_{t+s}\left(P_{t+s+1}^{h} \pi_{t+s+1}\right) / \pi_{t+s+1}}{P_{t+s}^{h}-m_{t} E_{t+s}\left(P_{t+s+1}^{h} \pi_{t+s+1}\right) / R_{t+s}^{e}} N W_{t+s}^{e, i}
$$

which is valid for $s \geq 1$. (Following the same argument as before, we are using the superscript $i$ on $N W_{t+s}^{e, i}$ for $s \geq 1$, in expressions (29) and (30) to emphasize that the net worth at future dates depends on the time $t$ banking choice via $R_{t}^{e, i}$, while such distinction is irrelevant for $\left.N W_{t}^{e}\right)$.

Then, given that $d_{t}^{k, i+1}=1 / n-d_{t}^{k, i}$, we next use the consumption function (24) 
together with the recursive representation of the net worth in (30), to express (28) as

$$
\frac{\beta^{e}}{1-\beta^{e}} E_{t}\left(\log N W_{t+1}^{e, i}-\log N W_{t+1}^{e, i+1}\right)=\alpha\left(2 d_{t}^{k, i}-1 / n\right)
$$

The intuition behind this equality is the following. By lowering its lending rate, bank $i$ tends to attract entrepreneurs that are further away from its own position (i.e. higher $\left.d_{t}^{k, i}\right)$, since a lower $R_{t}^{i, e}$ increases net worth at $t+1$, which, in turn, allows for higher consumption not only at $t+1$ but also in the future. We then apply the same reasoning to identify the pivotal entrepreneur between banks $i$ and $i-1$, denoted by $k^{\prime}$, to write the market share (extensive margin) of bank $i$ as $\widetilde{b}_{t}^{i}=d_{t}^{k, i}+d_{t}^{k^{\prime}, i}$, or using (31), as

$$
\widetilde{b}_{t}^{i}=1 / n+\left[\frac{1}{2 \alpha} \frac{\beta^{e}}{1-\beta^{e}} E_{t}\left(2 \log N W_{t+1^{-}}^{e, i} \log N W_{t+1}^{e, i+1}-\log N W_{t+1}^{e, i-1}\right)\right]
$$

This last expression makes clear that the extensive margin depends negatively on the number of competing banks. The second term in the right hand side of (32) reflects the fact that an increase in $R_{t}^{i, e}$ reduces the utility surplus that entrepreneurs obtain from borrowing from bank $i$ as compared with borrowing from either alternative, $i-1$ or $i+1$. That surplus is comprised of the discounted value stream of utility gains from $t+1$ on. Also the sensitiveness of the market share to variations in the surplus falls as $\alpha$ increases. If the utility cost of moving to other bank increases, then the incentive to do so will be reduced.

Finally, using the expression for $N W_{t+1}^{e, i}$ in (29) to obtain $\frac{\partial \widetilde{b}_{t}^{i}}{\partial R_{t}^{i, e}}$, and then imposing symmetry, we obtain the semi-elasticity of the market share,

$$
\widetilde{\Lambda}_{t}=\frac{n}{\alpha} \frac{\beta^{e}}{1-\beta^{e}}\left\{\left(\frac{R_{t}^{e}}{m_{t} E_{t}\left(\pi_{t+1}^{h} \pi_{t+1}\right)}-1\right) R_{t}^{e}\right\}^{-1} .
$$

where we have used the fact that in a symmetric equilibrium the market share of each 
bank is simply $1 / n$. Equation (33), when combined with (27), can also be expressed as

$$
\widetilde{\Lambda}_{t}=\frac{n}{\alpha}\left\{\frac{\beta^{e}}{1-\beta^{e}} m_{t} \frac{E_{t}\left(\pi_{t+1}^{h} \pi_{t+1}\right)}{R_{t}^{e}}\right\} \Lambda_{t} .
$$

This last expression is intuitive in light of the previous discussion around its intensive margin counterpart, $\Lambda_{t}$. As the time $t$ volume of collateral varies strongly with the lending rate, i.e. $\Lambda_{t}^{i}$ is high, so does the time $t+1$ net worth and, hence, consumption at that date. In short, a large value of $\Lambda_{t}^{i}$, given everything else, implies that a small increase in bank $i$ 's lending rate causes a large outflow of potential borrowers and vice versa. Furthermore, the fact that innovations in the net worth at $t+1$ unchain persistent wealth effects implies that a given degree of sensitiveness of the intensive margin gets amplified over the extensive margin, as formally captured by the term in brackets in the right side of (34). Finally, the effect of the term $n / \alpha$ (which can be thought as of representing the "effective degree of bank competition") on $\widetilde{\Lambda}_{t}^{e}$ is straightforward. High values of $n / \alpha$ imply a low degree of local monopoly power which, in turn, translates into higher sensitivity of the market share with respect to the lending rate.

We are now in a position to obtain the following expression for the symmetric equilibrium lending margin, $R_{t}^{e}-R_{t}^{d}$, by combining (21), (27) and (33),

$$
R_{t}^{e}-R_{t}^{d}=\frac{1-m_{t} E_{t}\left(\pi_{t+1}^{h} \pi_{t+1} / R_{t}^{d}\right)}{\eta m_{t} E_{t}\left(\pi_{t+1}^{h} \pi_{t+1} / R_{t}^{d}\right)-1} R_{t}^{d}
$$

where $\eta \equiv 1+\frac{n}{\alpha} \frac{\beta^{e}}{1-\beta^{e}}$.

Equation (35) shows in rather transparent manner how the model links collateral constraints with an imperfectly competitive banking sector to produce an endogenous external finance premium. This mechanism shares an important feature with the central proposition of BGG which contends that in a context with principal-agent conflicts the external finance premium paid by a borrower depends inversely on the soundness of the 
borrower's financial position, measured in terms of factors akin to the borrowers capacity to offer collateral, such as net worth, liquidity, cash flows, etc. In our set up, a negative relationship between the external finance premium and the borrowers capacity to pledge collateral, as captured by the term $m_{t} E_{t}\left(\pi_{t+1}^{h} \pi_{t+1} / R_{t}^{d}\right)$ in (35), obtains, as well. In contrast to the BGG framework, however, the channel we study in this paper emphasizes the idea that the degree of competition among lenders shapes the function that links a borrower's capacity to pledge collateral and the incentives faced by the lender when setting its lending rate. As such, we think of the mechanism explored here as working parallel and, potentially, amplifying or mittigating the one highlighted in BGG.

\section{Steady state analysis}

In this section we examine the long-run implications of changes in the degree of banking competition. To this aim, we first study the determinants of the steady-state lending margins and then, with the help of some numerical exercises, we analyze how the degree of banking competition influences some variables of interest.

\subsection{Steady state margin}

In the steady state the households subjective discount factor determines the real interest rate paid on deposits through the Euler equation (7), such that $r^{d}=1 / \beta$, where $r^{d} \equiv$ $R^{d} / \pi$. (We drop the time subscript to denote a variable in the steady state.) Then, by combining the steady state version of (7) with that of (18) we can express the multiplier associated with the borrowing constraints as $\xi^{e}=\left(1-\frac{\beta^{e}}{\beta} \frac{r^{e}}{r^{d}}\right) \lambda^{e}$, where $r^{e} \equiv R^{e} / \pi$. In the special case in which $r^{d}=r^{e}$ (i.e. zero real lending margins), the assumption that savers are more patient ensures that $\xi^{e}$ is positive, which implies that impatient entrepreneurs are financially constrained. Furthermore, if an interest rate differential arises in the steady- 
state equilibrium, then the value of the multiplier associated to the collateral constraint is lower than in the zero-margin case, since the willingness to borrow falls. As long as the corresponding lending markup $r^{e} / r^{d}$, is bounded above by $\beta / \beta^{e}$, entrepreneurs will optimally exhaust their borrowing limits in a steady state. We henceforth restrict our analysis to steady states in which this bound is respected. ${ }^{7}$

Using (35), we obtain the following expression for the lending margin,

$$
r^{e}-r^{d}=\frac{r^{d}-m}{\eta m-r^{d}} r^{d}
$$

This expression reflects the role of the different model components on the margin. In particular, we find that higher steady-state deposit rates $r^{d}$, which in the current context are to be understood as a lower discount factor for savers $\beta$, go hand in hand with higher margins. Stricter collateral requirements, as captured by lower $m$, also contribute to rise lending margins. This latter feature of the model reflects the idea that collateral constraints not only limit the amount of credit but may also influence its price. Finally, as expected, the margin is positively associated with larger banking monopolistic power, as captured by low values of $\eta$.

\subsection{Calibration}

To evaluate numerically the main properties of the model in the steady state we next calibrate its parameters to a quaterly time period. We start with the parameters governing the bank lending margins. The savers subjective discount factor $\beta$, is set in our central scenario at 0.9926 , which produces an annual real interest rate on deposits of 3 per cent. We then chose a discount factor for impatient entrepreneurs $\beta^{e}=0.97$, which is within

\footnotetext{
${ }^{7}$ In the dynamic stochastic analysis of next section we exploit a continuity argument and consider disturbances that are small enough so that the borrowing constraint also binds even when the economy temporarily departs from its steady state.
} 
the range of the normal bands used in the previous literature (see Iacoviello (2005) and the references therein). ${ }^{8}$ We also set $m=0.85$, which is in line with recent estimations for the U.S. ${ }^{9}$ We normalize the number of banks at 10 and set $\alpha=11$ that yields a real annual lending margin of 250 basis points. This is roughly the mean value of the interval considered by Christiano et al. (2007) who present some previous estimates for the U.S. economy.

As regards the parameters governing the distribution of the housing stock between the entrepreneurs and households sectors, we set $\vartheta=0.1$ and $\nu=0.05$, which together imply, first, that 20 per cent of the housing stock is owned by the entrepreneurs and, second, that the value of the stock of real estate used as a production factor is around 65 per cent of annual output. These values are in line with those reported by Iacoviello $(2005)$

The remaining parameters are more standard and we select values for them that are within the range usually considered in the literature. Specifically, $\mu, \varepsilon, \theta, \pi, \rho_{r}, \rho_{\pi}$ and $\psi$ equal $0.35,8,0.75,1.005,0.7,1.3$, and 2 , respectively.

\subsection{Long run effects of imperfect banking competition}

The panels in figure 1 represent the steady state value of several magnitudes along different levels of the annualized lending margin measured in real terms. The latter ranges from zero, which corresponds to a perfectly competitive banking sector (i.e. $\alpha=0$ ) to 400 basis points, which obtains by setting $\alpha=17.6$. All variables are normalized to take

\footnotetext{
${ }^{8}$ The degree of impatience implicit here is higher than the one calibrated by Krusell and Smith (1998) and Campbell and Hercowitz (2006a, 2006b), who set $\beta^{e}=0.985$. Since in our set up there is a positive lending margin, we choose a lower $\beta^{e}$ to ensure that in the vicinity of the steady state the borrowing constraint is always binding even when we consider high margins.

${ }^{9}$ Cambell and Hercowitz (2006b) calculate that the average equity share of new home owners in the U.S. for the last decade has been around $17.5 \%$., which is consistent with a loan-to-value ratio of $82.5 \%$. Likewise, Iacoviello (2005) obtains an estimation of the loan-to-value for U.S. entrepreneurial debt at $89 \%$.
} 
a value of 100 in the benchmark case described above (i.e. $\alpha=11$ ).

Figure 1.1 shows that the steady state level of output is positively related to the degree of banking competition. In fact, investment and consumption of both households and entrepreneurs (figures 1.2-1.4) all rise as $\alpha$ and, hence, lending margins fall. The sensitiveness of the long-run level of entrepreneurial consumption with respect to the lending margin is naturally higher than the one corresponding to households. Thus, putting things together, the model predicts that stronger banking competition "greases the economy's wheels" in the long run.

In order to get intuition into the mechanism behind the above result, it is helpful to examine how competition among banks affects the distribution of the housing stock between households and entrepreneurs. To this aim we next analyze how the user cost for an entrepreneur relative to that of a household varies with $\alpha$. Using (10) and (20) and substituting out for $\xi^{e}$, we can write the relative user cost for an entrepreneur vis-à-vis a household as,

$$
\frac{\varpi^{e}}{\varpi}=\frac{1-\beta^{e}-\left(\frac{1}{r^{e}}-\frac{\beta^{e}}{\beta} \frac{1}{r^{d}}\right) m}{1-\beta} .
$$

The relative user cost of housing as expressed in (37) is an increasing function of $\alpha$ (figure 1.6). This is an intuitive result. As $\alpha$ goes down, the interest rate paid by the entrepreneurs falls for any given a rate on deposits, $r^{d}$. Since the latter, which is the relevant intertemporal price for the households user cost, is unaffected by the fall in $\alpha$, using housing services becomes relatively less expensive for entrepreneurs, thus raising their demand, $H^{e}$ (see figure 1.5). The rise in the use of housing services in the production function (11), in turn, increases output. The latter pushes up wages and entrepreneurial net worth which trigger a rise in households and entrepreneurs consumption, respectively. 


\section{Dynamic analysis}

In this section we analyze the dynamics of a number of variables at the business cycle frequency in response to transitory shocks. The presence of collateral constraints and monopoly power in banking may induce very different responses of these variables as compared with models without these frictions. The role of housing as a pledgeable asset in a context with collateral constraints has been analyzed in Aoki, Proudman and Vlieghe (2004), Iacoviello (2005) and Calza, Monacelli and Stracca (2007), among others. Our main focus here is on the way in which short-run dynamics are affected by the presence of monopoly power in the banking industry.

Lending rates turn out to be key components of the transmission mechanism of shocks. As discussed before, weaker competition in the banking sector raises lending rates in the steady state, reducing consumption expenditure of savers and more so that of borrowers due to a reallocation of available collateral from the latter to the former. The responses of the main aggregate variables to various shocks will not be independent to the structure of this industry either. In what follows we illustrate this by analyzing the response function of some aggregate variables after three types of $A R(1)$ shocks: i) a monetary policy shock affecting the Taylor rule (with autorregressive coefficient $\rho_{r}=0.1$ ), ii) a technology shock affecting the productivity parameter $A\left(\rho_{A}=0.9\right)$; and iii) a credit-crunch shock defined as a temporary deviation of the pledgeability ratio $\left(m_{t}\right)$ with respect to its steady-state value $\left(\rho_{m}=0.95\right)$.

\subsection{Monetary policy shocks and banking competition}

Herein we focus on the effects of an unanticipated temporary monetary shock, implemented as a positive innovation $\epsilon_{t}^{R}$ in the monetary policy rule (22), that raises the nominal rate $R_{t}^{d}$. Figure 2.1 shows the accumulated response of output under the bench- 
mark calibration with long-run annual real lending margins of 250 b.p., and under a perfectly competitive banking sector, i.e. $\alpha=0$ and a zero margin. This figure shows that weaker competition in the banking industry tends to induce a milder and less persistent response of output. Specifically, the accumulated output loss in the economy with perfectly competitive banks is 27 per cent higher than in the benchmark case.

In order to get intuition on the previous numerical findings, we next focus on three important channels through which monetary shocks affect the variables of this economy: sticky prices in the manufacturing sector, endogenous lending margins and net worth effects.

Price rigidity. The presence of nominal rigidities has the usual effect in this model. The interest rate innovation causes an upward reaction of the real interest rate that diminishes consumption, via intertemporal substitution, and investment spending. From causal inspection of figure 2.2 , it is clear that price rigidity is unlikely to account for the sizeable differences in the output response. In fact the dynamics of inflation across banking structures are remarkably similar and that implies that the sacrifice ratio, in terms of output loss relative to inflation, is also significantly higher in the economy with a more competitive banking industry.

Endogenous lending margins. The contribution of rigid prices to the dynamics of output via higher real interest rates is reinforced by the countercyclical response of real lending margins in the economies with banking monopolistic power (see figure 2.3). The following expression is the log-linearized version of the margin equation (35), in which both sides have been deflated by expected inflation in order to deal with real margins and interest rates,

$$
\left(\widehat{r}^{e-r^{d}}\right)_{t}=c_{1} \widehat{r}_{t}^{d}-c_{2} \widehat{\pi}_{t+1}^{h}
$$

where a hatted variable denotes deviations of that variable with respect to its steady state value. $r_{t}^{e}$ and $r_{t}^{d}$ are the ex ante real interest on loans and deposits, respectively, i.e. $r_{t}^{e}=$ 
$R^{e} / \pi_{t+1}$ and $r_{t}^{d}=R^{d} / \pi_{t+1}$. The multipliers are $c_{1} \equiv\left[\eta m / r^{d}+r^{d} /\left(r^{e}-r^{d}\right)\right] /\left(\eta m / r^{d}-1\right)$ and $c_{2} \equiv\left[\eta m / r^{d}+m /\left(r^{e}-r^{d}\right)\right] /\left(\eta m / r^{d}-1\right)$. Thus, from (38) we see that the positive impact of the monetary shock on the real lending margin is the net result of two opposite effects. On the one hand, the initial increase in the real marginal cost faced by banks $\left(\widehat{r}_{t}^{d}>0\right)$, gives rise to an increase in the real lending rate $\left(\widehat{r}_{t}^{e}>0\right)$, that makes the individual demand for funds less sensitive with respect to $\widehat{r}_{t}^{e}$, i.e. both intensive and extensive margin semielasticities fall. On the other hand, positive house price inflation following the shock, $\left(\widehat{\pi}_{t+1}^{h}>0\right.$; see figure 2.4), unchains the opposite effect. Intuitively, as the house price recovers towards its steady state value, a unit of internal funds invested in housing allows an entrepreneur to rise more debt since the resale value of housing is growing. This, in turn, raises both the leverage ratio $B_{t}^{e} / P_{t}^{h} H_{t}^{e}$, and the sensitiveness of the individual demand for bank loans. Thus, this latter effect dampens to a large extent the upwards response of the margin.

Taking the response of lending margins in isolation, one would conclude that stronger banking competition helps to dampen output fluctuations following monetary shocks. Since the interest rate faced by investing agents rises more than one-to-one respect to the policy rate, weaker banking competition leads to an amplification of the effects of original disturbance. The effect of banking competition operating through the lending margin is akin to the financial accelerator mechanism in BGG. However, our economy also incorporates borrowing limits and nominal debt. Both elements, as explained below, interact in the presence of a monetary shock to undo the previous stabilizing role of stronger banking competition that obtains through a reduction in the countercyclical pattern of lending margins.

Collateral and net worth effects. The differences in the accumulated output response for the two levels of banking competition in figure 2.1 are mainly due to the strong influence of interest rate margins on the behavior of constrained entrepreneurs. In fact, the 
downwards adjustment in the consumption of savers is in line with what one would expect in a standard Ricardian environment free of financial frictions (see figure 2.5). In short, such response is small, for the only channel through which movements in the interest rate affect consumption of households in this economy is the intertemporal allocation of wealth. The usual substitution and income effects arising from changes in the deposit real interest rate operate in different directions, yet the reduction in other sources of income associated with the fall in the level of activity generates a negative income effect that leads to a small negative net response of consumption.

This mild reaction in the consumption of households contrasts with that corresponding to entrepreneurs (figure 2.6). The unexpected rise in the interest rate erodes their net worth, thus reducing their consumption. Hence, both the substitution and the wealth effects operate in the same direction. Unlike in the case of households, entrepreneurs consumption is very sensitive to the degree of competition in the banking sector. In particular, the corresponding impact response of entrepreneurs consumption is 20 per cent higher under perfect banking competition than in the benchmark case. This naturally follows from the fact that stronger competition among banks drives lending rates down which raises leverage ratios. To gain some further insights into this latter mechanism, it is helpful to analyze the impact response of entrepreneurs' net worth at the time of the shock $(t=1)$. To this aim, we combine (14), holding as an equality, and (23), to express the entrepreneurial net worth at $t=1$ as

$$
N W_{1}^{e}=\left(1-m \frac{\pi}{\pi_{1}}\right) P_{1}^{h} H^{e}+\nu Y_{1} / X_{1}
$$

Log-linearizing (39) around the steady state gives the following expression for the relative deviation of net worth on impact (i.e. at $t=1$ ), 


$$
\widehat{N W}_{1}^{e}=\beta^{e} \frac{r^{e}}{r^{e}-m}\left[\widehat{P}_{1}^{h}+m \widehat{\pi}_{1}+\nu \frac{Y}{X}\left(\widehat{Y}_{1}-\widehat{X}_{1}\right)\right]
$$

The term, $r^{e} /\left(r^{e}-m\right)$ in the above expression corresponds to the steady state ratio of housing investments over net worth, i.e. $P^{h} H^{e} / N W^{e}$, which can also be expressed as an increasing function of the leverage ratio, $B^{e} / P^{h} H^{e}$, as $1 /\left(1-B^{e} / P^{h} H^{e}\right)$. Clearly, the leverage ratio is negatively related to $r^{e}$ and, hence, according to (36), it increases with the degree of baking competition. Higher leverage ratios, in turn, amplify the magnitude of changes in the house price, the real value of maturing debts, debt-deflation and the marginal productivity of entrepreneurial real estate, all of which are negative. In this context, stronger banking competition tends to amplify the original negative effect on debtors' net worth. As this happens, their ability to obtain external funding in the current period falls (see figure 2.7) even though stronger banking competition keeps margins lower as discussed above. Then, lower access to credit unchains a negative effect on debtors demand for housing that puts extra downward pressure on housing prices and, hence, on debtors net wealth, reducing their ability to obtain external funding and curtailing their demand for consumption and capital, with the latter driving down capital investment. These net worth and collateral effects, which quantitatively dominate the margin effect, lie behind the positive association between high competition and larg falls in housing prices, aggregate consumption, capital investment and output.

\subsection{Technology shocks}

Figure 3.1 depicts the 40-period accumulated output response following a negative technology shock. As before, the response is stronger in the economy with a perfectly competitive banking sector. Yet, differences in the output response are of a much smaller magnitude in this case. The response under a perfectly competitive banking sector is 7 per cent lower than in the benchmark case. The reason for this milder incidence of the 
banking structure comes from the presence of two opposite effects of banking competition on the borrowers' net worth. Following a negative shock the fall in the housing price reduces the value of collateral in hands of entrepreneurs'. But this shock has a inflationary effect on impact that reduces the real value of maturing debts; this positive net worth effect is increasing in the amount of accumulated debt that is higher in economies with low interest rate margins (see (40)). Hence, more competitive banking industries induce stronger responses of both the value of housing and debt repayments. Although the first effect dominates, the sensitivity of net worth, and hence consumption, is much lower than in the case of a monetary shock.

As with the monetary shock, the role played by the net worth effect on the response of aggregate output is reflected on the unequal reaction of consumption across agents. Whereas the impact response of households consumption (figure 3.5) is 0.61 per cent of its steady state value in the benchmark, the fall in entrepreneurs' consumption is comparatively larger (around 4 per cent in the benchmark; see figure 3.6). The drop in households consumption is entirely due to the fall in output, real wages and the value of housing and productive capital. Entrepreneurs, on the other hand, have another important determinant of consumption, namely the value of the collateral that determines the borrowing limit. The fall in housing prices reduces their wealth and, hence, their ability to pledge collateral thus pushing down both current consumption and debt (3.7). Also, the unequal response of output across different degrees of banking competition is mostly explained by the differences obtained in consumption spending by constrained agents, while the reaction of households consumption is virtually unaffected by the degree of competition in the banking industry.

The reduction in volatility of macroeconomic variables associated with high market power in the banking industry is in stark contrast with the implication of most previous models that incorporate a banking sector. Aliaga-Díaz and Olivero (2006), Stebunovs 
(2008) and Mandelman (2006) all develop models with imperfect banking competition and find that higher monopolistic power is associated with a larger output response to productivity shocks. Our model shares with these the fact the more competitive banking industries are associated with higher output in the steady-state as well as the countercyclical response of lending margins. However, as in the case of monetary shocks, the presence of collateral constraints that are alleviated by positive technology shocks, in particular through the rise in the housing price (figure 3.4) that fuels credit, dominates, thus making the output response stronger under perfect competition in banking. The latter additional channel, which is missing in the papers above, lies at the core of the positive link between banking competition and output response.

\subsection{A credit-crunch shock}

We next analyze the effects of an exogenous fall in the pledgeability ratio, $m_{t}$, that given everything else, reduces the borrowers credit capacity, hence a credit-crunch shock. Figure 4.1 shows the accumulated output loss over our benchmark 40-period horizon. In contrast to the previous monetary and technology shocks, now the accumulated output response is larger in the benchmark economy with imperfect banking competition, with noticeable differences between both cases. In particular, the output loss in the benchmark case is 28 per cent higher than in the perfect competition case.

An obvious direct consequence from this shock is a fall in the housing price due to the tightening of the borrowing constraint (14). This, in turn, triggers a negative effect on entrepreneurs' net worth, which further depresses housing prices. Thus, on impact, this shock unchains a propagation mechanism that is, qualitatively, identical to the one discussed before in the context of a monetary shock. Yet, now the impact response of entrepreneurial consumption is almost identical in the two cases under study. This is due to the fact that the lending margin in the benchmark case now rises by a much larger 
amount since, according to (35), the margin is negatively related to $m_{t}$. Formally, the log-linearized expression for the real margin (38), now becomes

$$
\left(\widehat{r^{e}-r^{d}}\right)_{t}=c_{1} \widehat{r}_{t}^{d}-c_{2}\left(\widehat{\pi}_{t+1}^{h}+\widehat{m}_{t}\right)
$$

This last equation shows that the shock to $m_{t}$ produces a first-order effect on the lending margin in the benchmark case with imperfect banking competition, as illustrated in figure 4.3. The strong response of the margin means that the real interest rate on loans rises far more in this case than under a perfectly competitive banking sector. In turn, a higher interest on loans tantamount to a further tightening of the borrowing constraint since the expected next period resale value of the entrepreneur's housing stock is more heavily discounted, thus, reducing the leverage ratio. The latter implies a lower housing demand which tends to further depress housing prices and entrepreneurs' net worth. This effect explains why the small differences between the benchmark and the competitive cases in terms of the impact response of housing prices, entrepreneurs' net worth, consumption and debt (see figures 4.4 and 4.7 for the response of housing prices and debt, respectively).

Furthermore, as time passes, a persistent positive deviation of the lending margin with respect to its steady state value in the benchmark case tends to slow down the recovery of housing prices and entrepreneurs' net worth and debt capacity, all of which remain well below their stationary levels for a long time. This explains why, in contrast to the monetary and technology shocks analyzed before, the accumulated output loss over a sufficiently long horizon is higher when banks enjoy monopolistic power, as shown in figure 4.1. 


\section{Conclusions}

We develop a dynamic general equilibrium model with an imperfectly competitive bankloans market and collateral constraints that tie investors' credit capacity to the value of their real estate holdings. Banks set optimal lending rates taking into account the effects of their price policies on their market share and on the volume of funds demanded by each customer.

We find that lending margins have a significant effect on aggregate variables. Over the long run, fostering banking competition increases total consumption and output by triggering a reallocation of available collateral towards investors. However, the effects of banking competition on the economy's response to exogenous perturbations are more complex due to the existence of two competing effects. On the one hand, lower lending margins imply higher leverage ratios which tend to exacerbate the short-run response of housing prices, consumption and output, through the familiar net worth acceleration mechanism induced by endogenous borrowing constraints. On the other hand, lower lending margins promote a faster recovery of the borrowers' net worth and, hence, their borrowing and production capacity in face of an adverse shock. Which of the previous conflicting forces dominates depends crucially on the nature of the shock hitting the economy.

In face of a contractionary monetary shock output exhibits a larger and more persistent fall as banking competition heightens. After the shock, the negative debt-deflation and collateral (housing price deflation) effects both get amplified in the presence of low lending margins and high leverage ratios. However, as banking competition intensifies, the positive response of lending margins following the shock becomes weaker, which mitigates the downwards response of housing prices, debt and output. This latter effect, however, is found to be very small in the case of a monetary shock and insufficient to compensate the previous negative net worth effect. 
However, the previous conclusion does not hold when we study the effects of credit crunch-type shocks that reduce the degree of pledgeability of collateralizable assets. In this case, we find that stricter credit rationing leads banks to pursue aggressive margin increases which, in turn, tend to postpone the economy's recovery for a longer time. Hence, we find that stronger banking competition works to reduce the total output loss over longer horizons by accelerating the recovery. 


\section{References}

[1] Adams, R. M., and D. F. Amel (2005): "The Effects of Local Banking Market Structure on the Bank-Lending Channel of Monetary Policy," Finance and Economics Discussion Series 2005-16, Board of Governors of the Federal Reserve System.

[2] Aliaga-Díaz, R. and M. Olivero (2006): "Macroeconomic Implications of Market Power in Banking". Mimeo.

[3] Aoki, K., J. Proudman and G. Vlieghe, (2004): "House prices, consumption, and monetary policy: a financial accelerator approach", Journal of Financial Intermediation 13, 414-435.

[4] Bernanke, B. and M. Gertler (1989), "Agency Costs, Net Worth, and Business Fluctuations", American Economic Review, March, Vol. 79(1), pp. 14-31.

[5] Bernanke, B., M. Gertler and S. Gilchrist (1999), "The Financial Accelerator in a Quantitative Business Cycle Framework," in J.B. Taylor and M. Woodford, eds., Handbook of Macroeconomics, vol. 1C. Amsterdam: Elsevier Science, North-Holland.

[6] Calvo, G. (1983): "Staggered Prices in a Utility-Maximizing Framework," Journal of Monetary Economics 12: 383-398.

[7] Calza, A., Monacelli, T. and Stracca, L. (2007): "Mortgage Markets, Collateral Constraints and Monetary Policy: Do Institutional Factors Matter?". Center for International Studies, WP 2007/10.

[8] Campbell, J. R., and Z. Hercowitz (2006a): "The Role of Collateralized Household Debt in Macroeconomic Stabilization," mimeo.

[9] Campbell, J. R., and Z. Hercowitz (2006b): "Welfare Implications of the Transition to High Household Debt," mimeo.

[10] Canzoneri, M., R. Cumby, B. Diba, and D. López-Salido (2008): "Monetary Aggregates and Liquidity in a Neo-Wicksellian Framework," Journal of Money, Credit and Banking, forthcoming.

[11] Chiappori, P.-A., D. Pérez-Castrillo, and T. Verdier (1995): "Spatial Competition in the Banking System: Localization, Cross Subsidies and the Regulation of Deposits Rates," European Economic Review, 39, 889-918.

[12] Christiano, L., R. Motto, and M. Rostagno (2007): "Financial Factors in Business Cycles," mimeo Northwestern University.

[13] Dell'Ariccia, G. (2001): "Asymmetric Information and the Structure of the Banking Industry," European Economic Review 45(10): 1957-1980.

[14] Davis, M., and J. Heathcote (2005): "Housing and the Business Cycle," International Economic Review 46(3): 751-784. 
[15] Degryse, H., and S. Ongena (2005): "Distance, Lending Relationships, and Competition," Journal of Finance, 60, 231-266.

[16] Freixas, X., and J.-C. Rochet, (1997): Microeconomics of Banking. Cambridge: MIT Press.

[17] Gerali, A., S. Neri, L. Sessa, and F. Signoretti (2008): "Credit and Banking in a DSGE Model," Banca D'Italia, mimeo.

[18] Goodfriend, M. , B. McCallum (2007): "Banking and interest rates in monetary policy analysis: A quantitative exploration", Journal of Monetary Economics 54 1480-1507.

[19] Goodhart, C., B. Hofmann and M. Segoviano (2004): "Bank Regulation and Macroeconomic Fluctuations," Oxford Review of Economic Policy, 20(4): 591-615.

[20] Huelsewig, O., E. Mayer, and T. Wollmershaeuser (2006): "Bank Behavior and the Cost Channel of Monetary Transmission," CESIFO WP no. 1813.

[21] Iacoviello, M. (2005): "House Prices, Borrowing Constraints, and Monetary Policy in the Business Cycle," American Economic Review 95, no. 3: 739-764.

[22] Kiyotaki, N. and J. H. Moore (1997). "Credit Cycles," Journal of Political Economy, 105, 211-248.

[23] Krusell, P., and A. A. Smith (1998). "Income and Wealth Heterogeneity in the Macroeconomy.," Journal of Political Economy, 106: 867-896.

[24] Mandelman, F. (2006), "Business Cycles: A Role for Imperfect Competition in the Banking System", Federal Reserve Bank of Atlanta, working paper no.21.

[25] Petersen, M.A. and R. Rajan (1995): "The Effect of Credit Market Competition on Lending Relationships," Quarterly Journal of Economics, 110, 407-443.

[26] Petersen, M.A. and R. Rajan (2002): "Does Distance Still Matter? The Information Revolution in Small Business Lending," Journal of Finance, 57: 2533-2570.

[27] Repullo, R. (2004): "Capital Requirements, Market Power, and Risk-taking in Banking," Journal of Financial Intermediation, 13, 156-182.

[28] Salop, S. (1979): "Monopolistic Competition with Outside Goods," Bell Journal of Economics 10: 141-156.

[29] Stebunovs, V. (2008): "Finance as a Barrier to Entry: U.S. Bank Deregulation and the Business Cycle", mimeo, Board of the Governors of the Federal Reserve System. 
Figure 1. Steady State levels for different degrees of banking competition.

1.1 Output

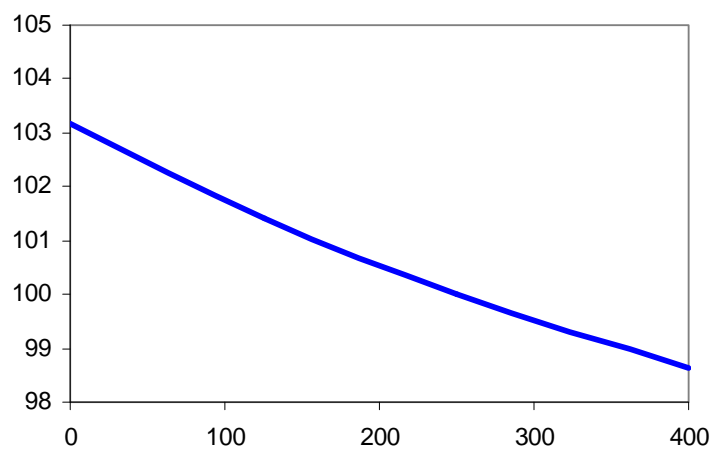

\subsection{Households Consumption}

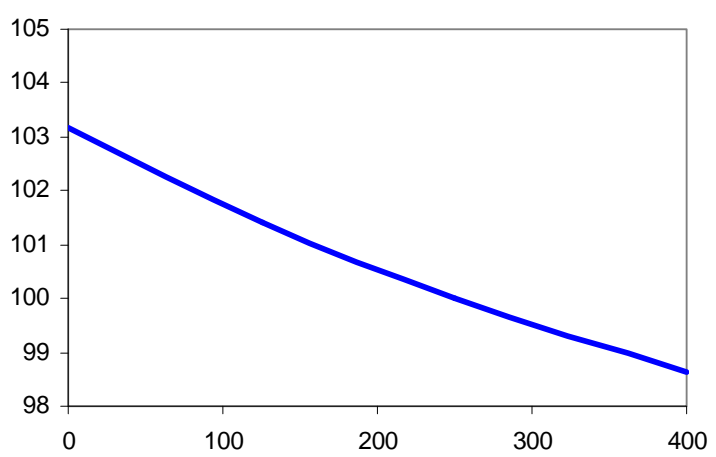

1.5. Entrepreneurs Housing

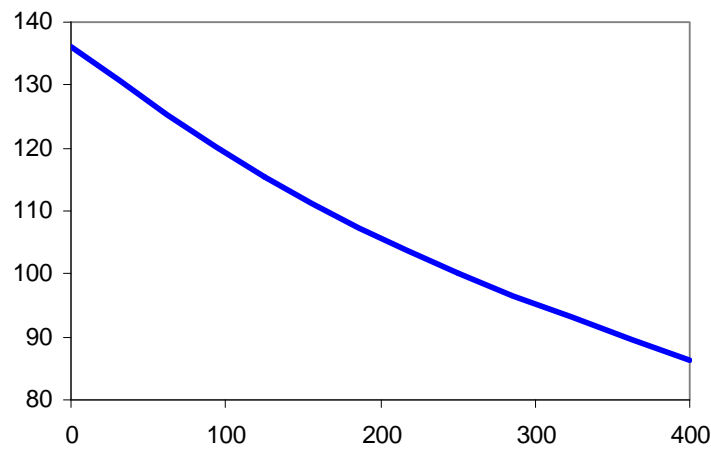

1.2. Investment

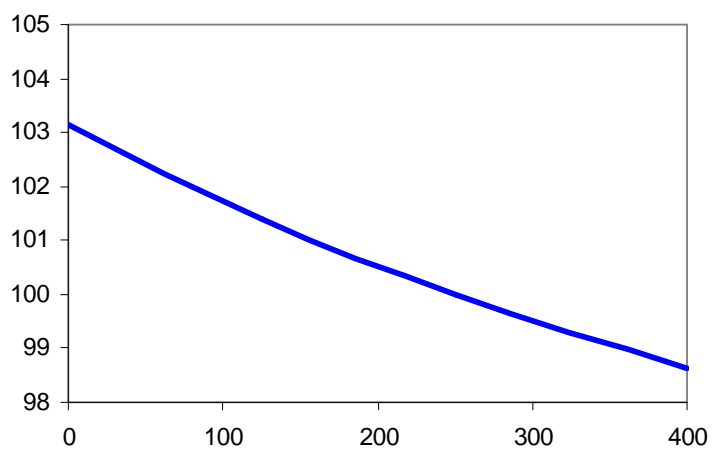

\subsection{Entrepreneurs Consumption}

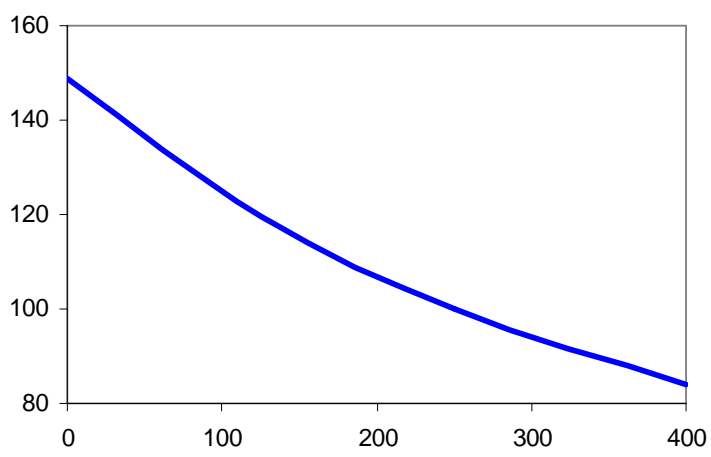

1.6. Relative User Cost

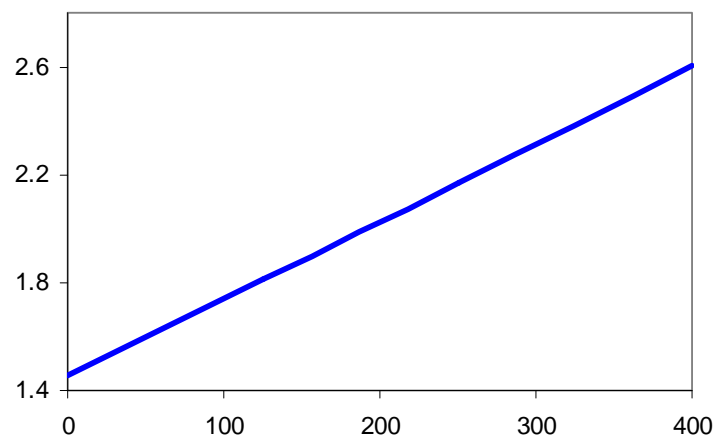

Horizontal axis: real lending margin (basis points, annual);

Vertical axis: Figs. 1.1-1.5, normalized levels (benchmark with 250 basis point $=100$ );

Vertical axis: Fig. 1.6, value of the realtive user cost 
Figure 2. Impulse responses. Monetary shock.

2.1 Output accumulated

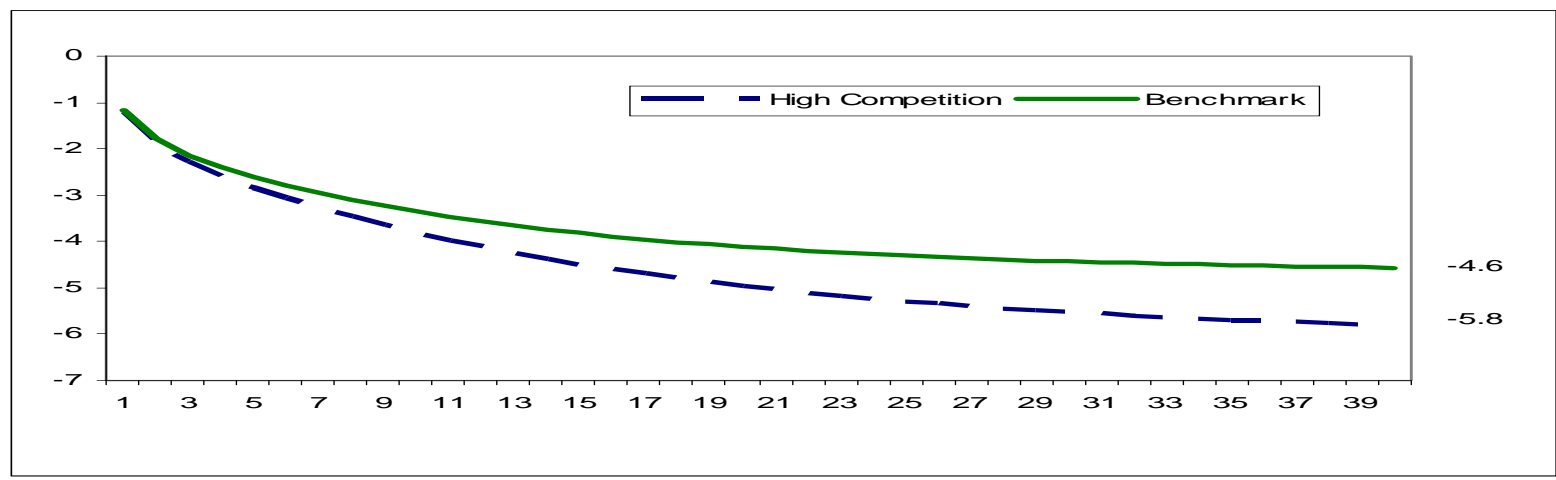

2.2. Inflation

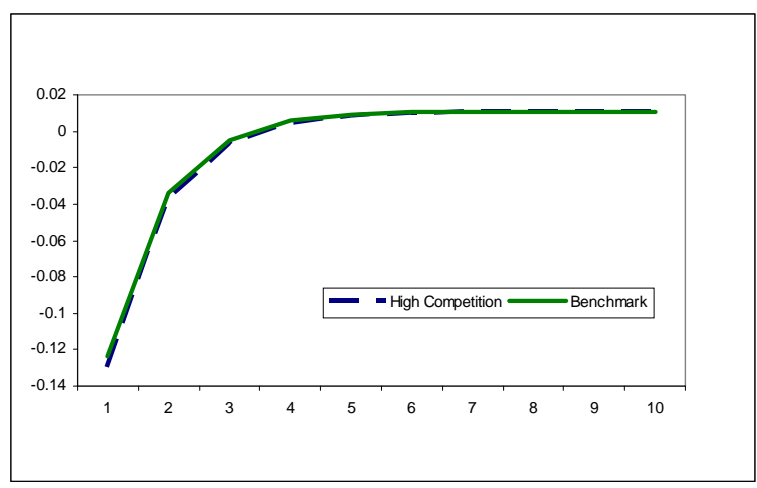

2.4. House Price

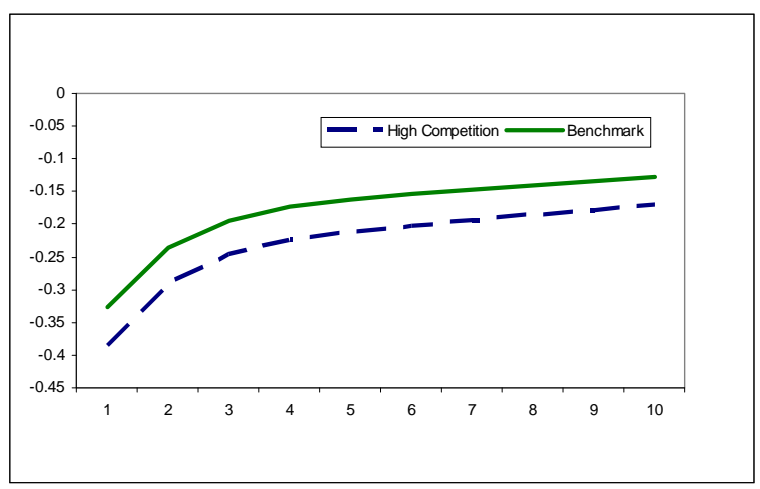

2.6. Entrepreneurs Consumption

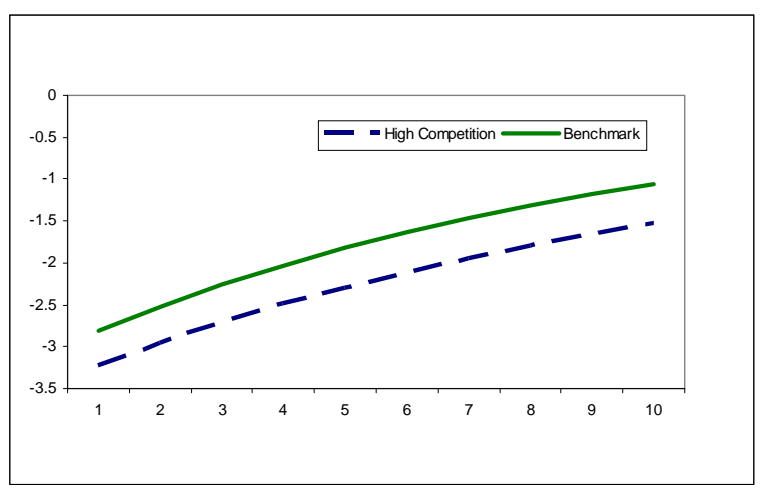

2.3. Real Margin

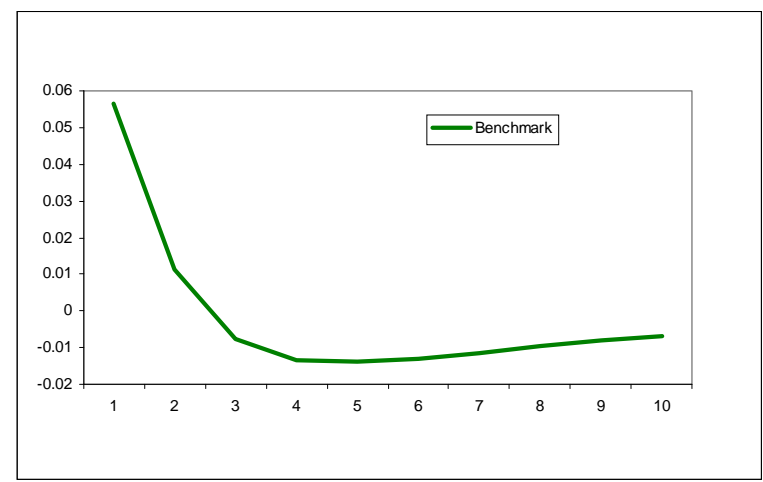

2.5. Households Consumption

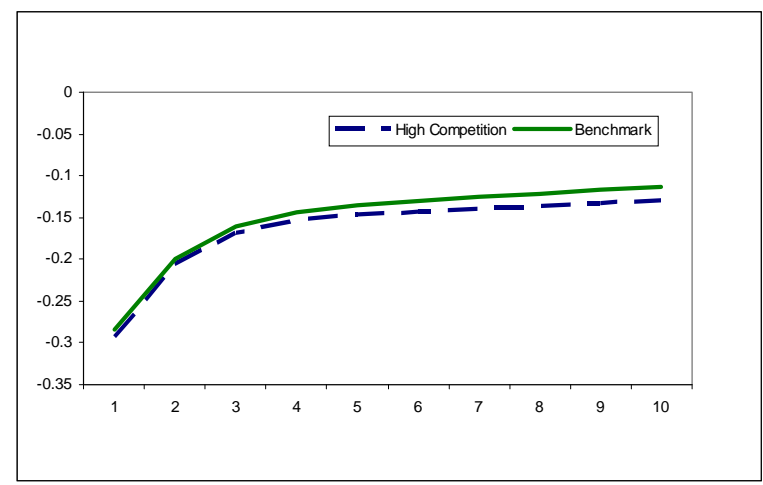

2.7. Debt

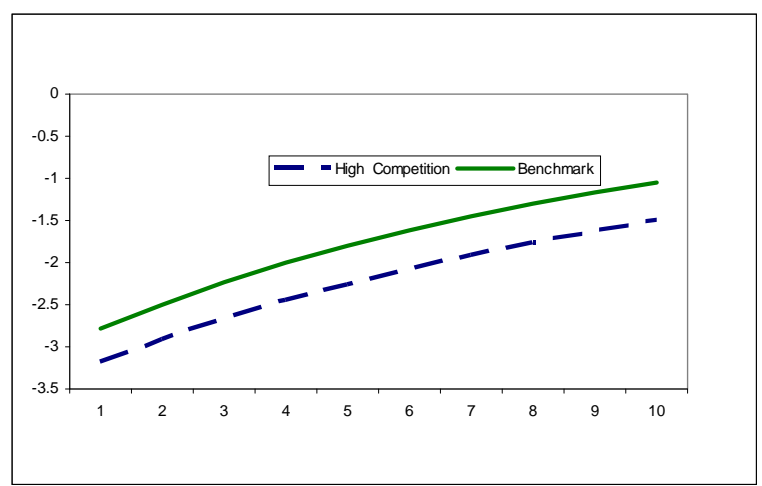

Horizontal axis: quarters after the shock.

Vertical axis: Fig. 2.1: Accumulated deviation from the steady state value in percentage points Vertical axis: Figs. 2.2-2.7: Deviation from the steady state value in percentage points 
Figure 3. Impulse responses. Technology shock.

3.1 Output accumulated

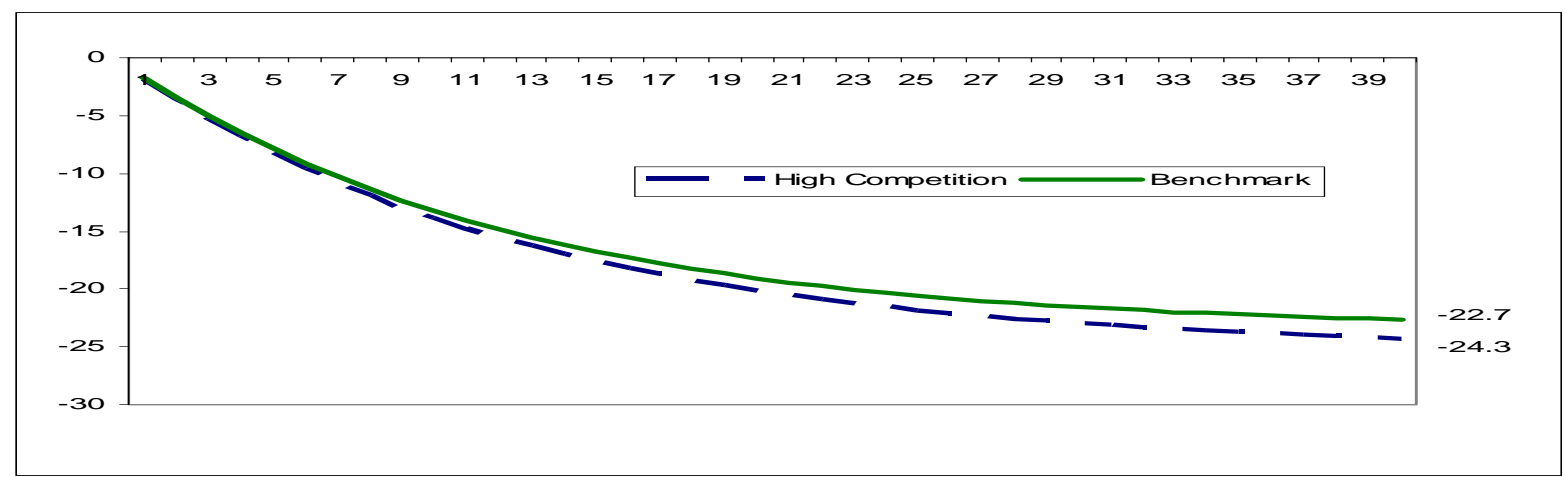

3.2. Inflation

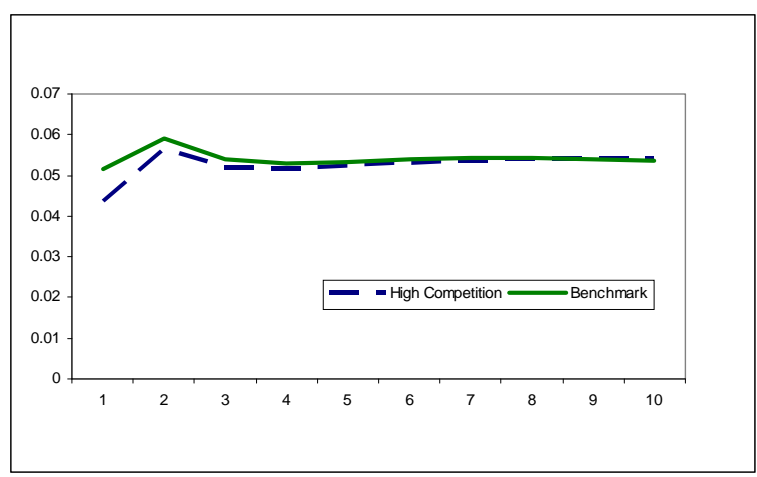

3.4. House Price

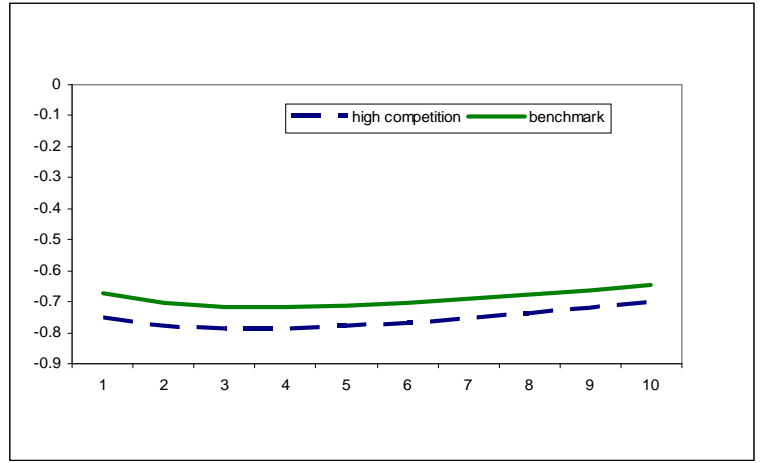

3.6. Entrepreneurs Consumption

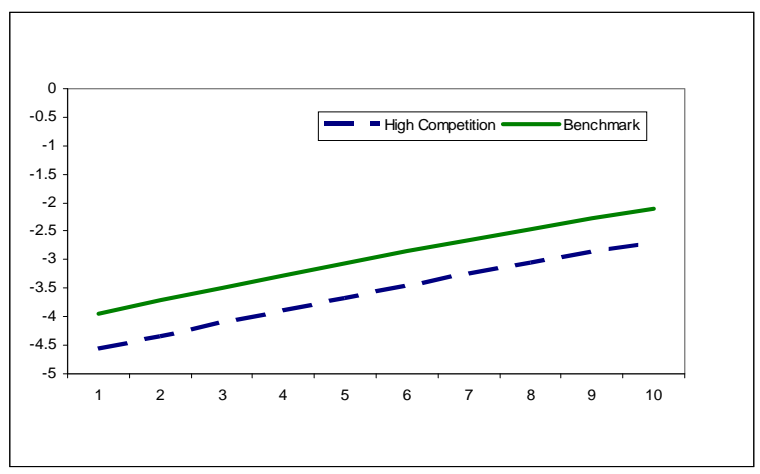

3.3. Real Margin

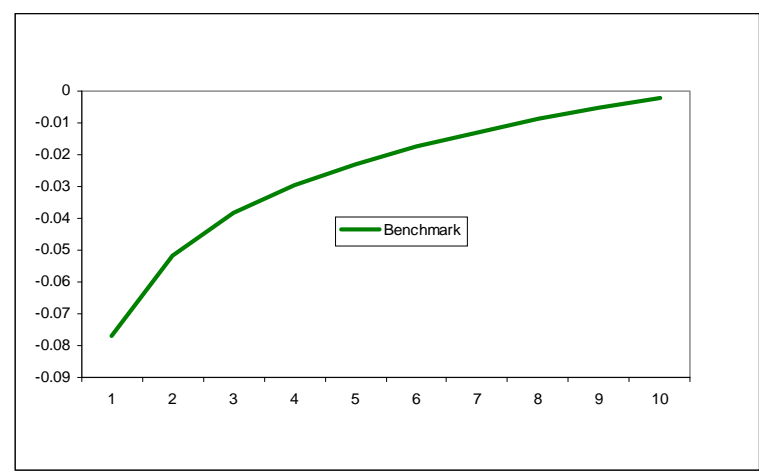

3.5. Households Consumption

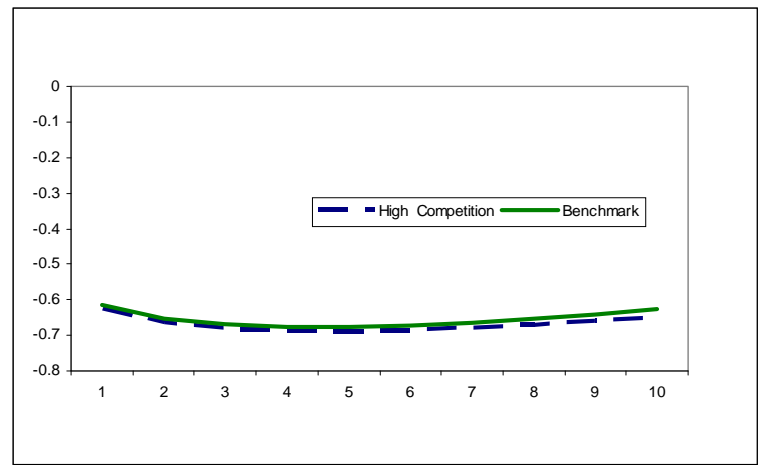

3.7. Debt

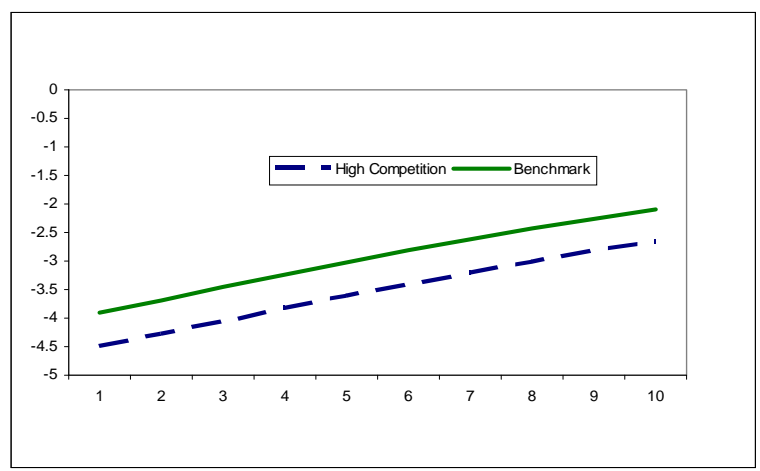

Horizontal axis: quarters after the shock.

Vertical axis: Fig. 3.1: Accumulated deviation from the steady state value in percentage points Vertical axis: Figs. 3.2-3.7: Deviation from the steady state value in percentage points 
Figure 4. Impulse responses. Credit-crunch shock

4.1 Output accumulated

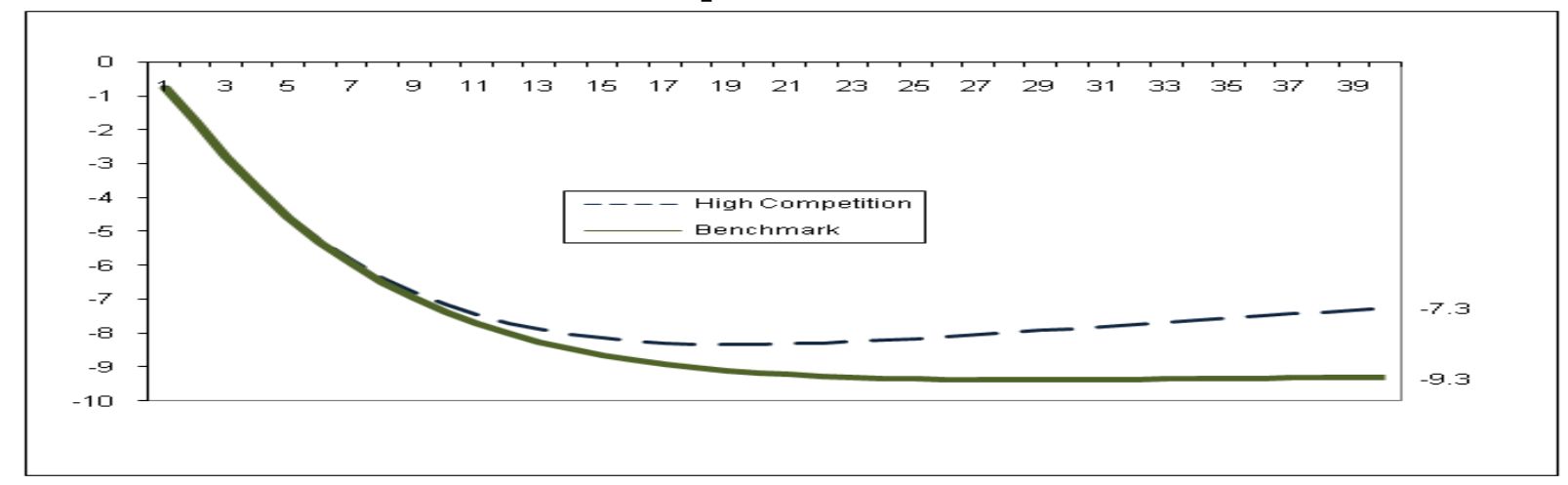

\subsection{Inflation}

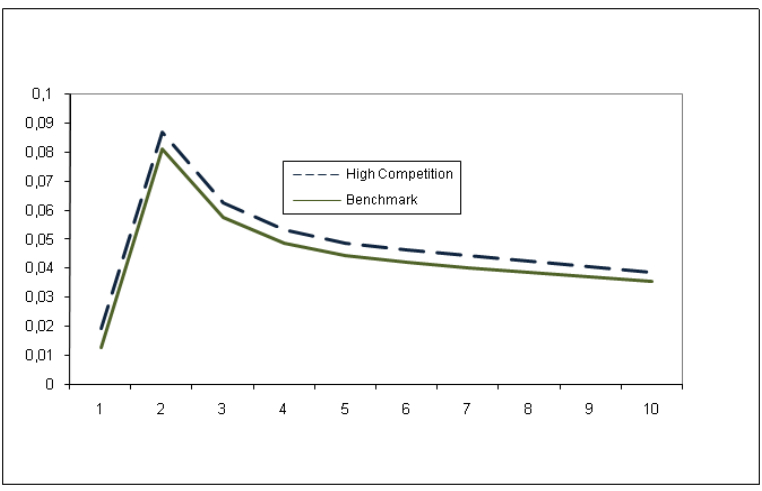

4.4. House Price

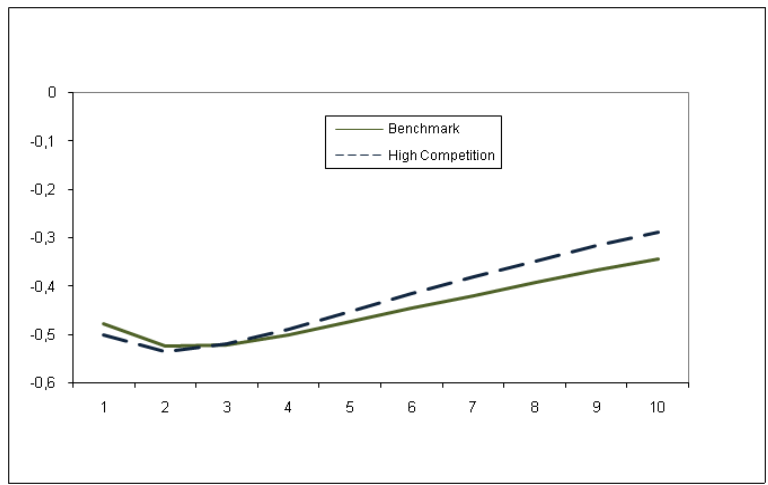

4.6. Entrepreneurs Consumption

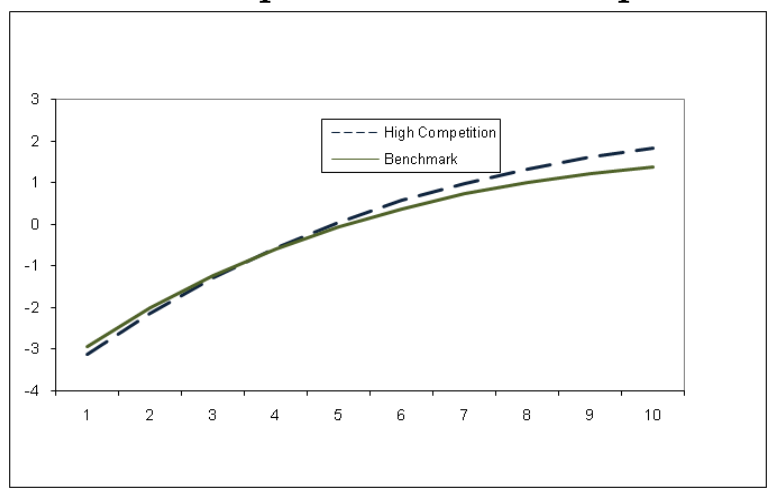

4.3. Real Margin

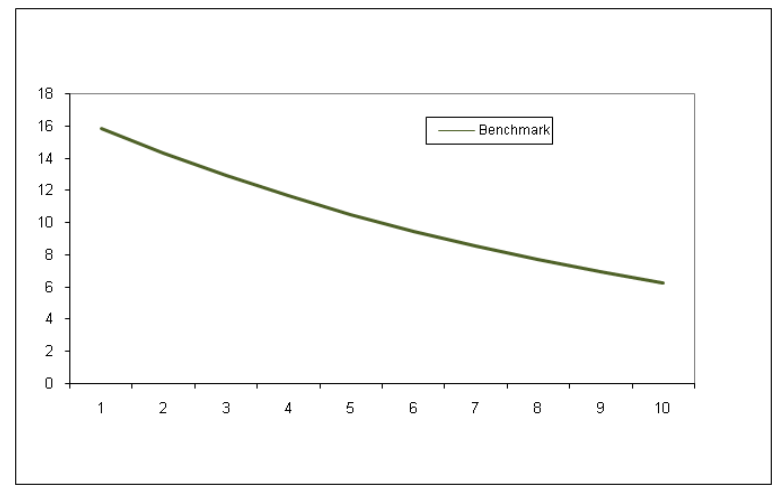

4.5. Households Consumption

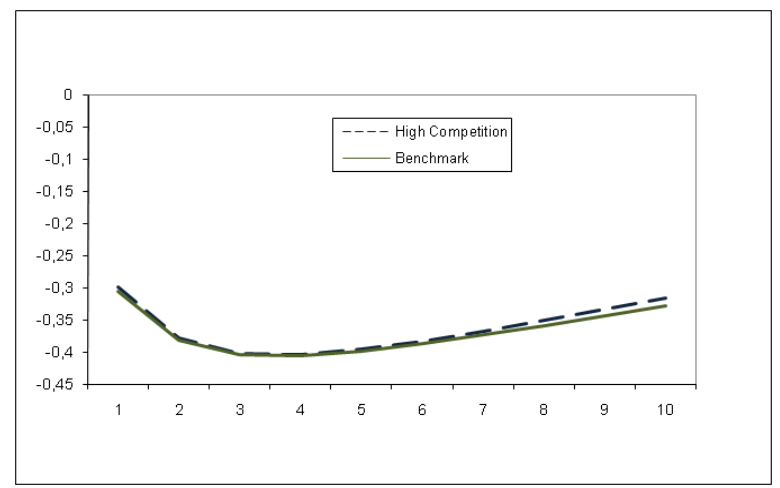

4.7. Debt

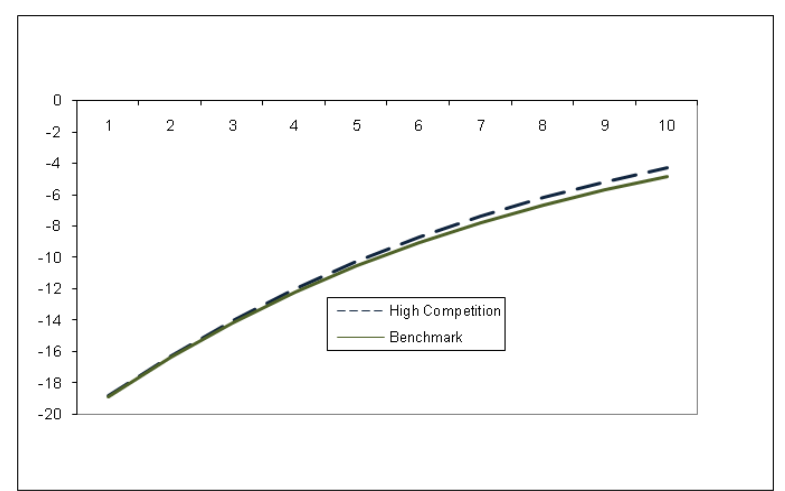

Horizontal axis: quarters after the shock.

Vertical axis: Fig. 4.1: Accumulated deviation from the steady state value in percentage points Vertical axis: Figs. 4.2-4.7: Deviation from the steady state value in percentage points 
